\title{
Keys to the Costa Rican species of paper wasps (Hymenoptera: Vespidae: Polistinae)
}

\author{
J. Pablo Valverde ${ }^{1}$, Paul Hanson ${ }^{2 *} \&$ James Carpenter $^{3}$ \\ 1. Department of Evolutionary Biology, Bielefeld University, Bielefeld, Germany; wiedehopf30@hotmail.co.uk \\ 2. Escuela de Biología, Universidad de Costa Rica, San Pedro 11501-2060, San José, Costa Rica; paul.hanson@ucr.ac.cr \\ 3. Division of Invertebrate Zoology, American Museum of Natural History, Central Park West at 79th Street, New York, \\ NY 10024, U.S.A; carpente@amnh.org \\ * Correspondence
}

Received 09-XI-2017. Corrected 13-XII-2018. Accepted 17-I-2019.

\begin{abstract}
Paper wasps (subfamily Polistinae) are one of the four main groups of eusocial insects in the Neotropics. They are medically important for the frequent stings inflicted on humans, but at the same time are valuable predators of pest insects. Nonetheless, there are no updated keys for the identification of the Central American species. Here we provide keys to the 18 genera and 106 species known to occur in Costa Rica, illustrated with one hundred original line drawings.
\end{abstract}

Key words: Polistinae, social wasps, identification, taxonomic keys.

Valverde, J. P., Hanson, P., \& Carpenter, J. (2019). Keys to the Costa Rican species of paper wasps (Hymenoptera: Vespidae: Polistinae). Revista de Biología Tropical, 67(2) Suplemento, S174-S199.

In the Neotropics most wasp stings are due to paper wasps, yet these wasps are important predators of other insects and can be useful in biological control. They are one of the four main groups of eusocial insects present in the region (along with stingless bees, ants, and termites) and they derive their name from the fact that their nests consist predominantly of masticated wood fibers (Wenzel 1998). There is a considerable amount of literature on the biology of paper wasps, much of which was reviewed by West-Eberhard, Carpenter, \& Hanson (2006). Despite their importance and interesting biology, the only published keys currently available for identifying the Costa Rican species are those of Richards (1978), which are for the entire New World and often difficult to use. The objective of this paper is to provide more accessible keys for identifying the 106 described species of Polistinae known to occur in Costa Rica.

\section{MATERIALS AND METHODS}

Many morphological characters used in the keys were taken from existing literature, but others were based on an examination of specimens. Literature sources included Richards (1978) and subsequent descriptions of new species: Mischocyttarus pelor (Carpenter \& Wenzel, 1988), Agelaia melanopyga and A. pleuralis (Cooper, 2000), Chartergellus golfitensis (West-Eberhard, Carpenter, Gelin, \& Noll, 2010), Metapolybia mesoamerica (Smethurst \& Carpenter, 1997), M. servilis (Cooper, 1999), Polybia selvana (Carpenter \& Kojima, 2002) and Protopolybia collombiana 
(Dos Santos Junior, Silveira, \& Carpenter, 2015). There have also been a few changes in species-level nomenclature (Snelling, 1983; Carpenter, 1999, 2012; Silveira, 2006; Silveira, Silva, \& Felizardo, 2015). Specimens were examined based on collections in the American Museum of Natural History, the Zoology Museum of the University of Costa Rica, and the National Museum of Costa Rica (formerly INBio).

The characters used in the keys refer to females except where noted. Terminology follows that used in the above literature and the following abbreviations are used in the keys: $\mathrm{S}$ for metasomal sternum, $\mathrm{T}$ for metasomal tergum (e.g. $\mathrm{T} 1=$ first tergum), and $\mathrm{WL}$ is fore wing length. Nest characters refer to completed nests. Characters given in square brackets [ ] are supplementary aids to identification and are not necessarily exclusive to the particular genus or species. The scale bar in all figures is $1 \mathrm{~mm}$.

\section{RESULTS}

The keys include all 18 genera and the 106 named species currently known to occur in Costa Rica (Table 1). It should be noted that while we have attempted to make the keys useable by a nonspecialist, there are a few species that remain difficult to identify, requiring experience and sometimes comparison with identified specimens. The keys should be useful for identifying paper wasps in Nicaragua and Panama, but they will be less useful in more distant countries.

TABLE 1

Species and subspecies of Polistinae known to occur in Costa Rica

\begin{tabular}{|c|c|}
\hline $\begin{array}{l}\text { Tribe, Genus, } \\
\text { Subgenus }\end{array}$ & Species \\
\hline \multicolumn{2}{|l|}{ Polistini } \\
\hline Polistes $^{l}$ & $\begin{array}{l}\text { apicalis de Saussure, aterrimus de Saussure, bicolor Lepeletier, canadensis canadensis (Linnaeus), } \\
\text { carnifex carnifex (Fabricius), deceptor Schulz, dorsalis neotropicus Bequaert, erythrocephalus } \\
\text { Latreille, goeldii Ducke, infuscatus infuscatus Lepeletier, instabilis de Saussure, major major } \\
\text { Beauvois, myersi myersi Bequaert, occipitalis Ducke, oculatus Smith, pacificus Fabricius, } \\
\text { testaceicolor Bequaert, versicolor versicolor (Olivier) }\end{array}$ \\
\hline \multicolumn{2}{|l|}{ Mischocyttarini } \\
\hline \multicolumn{2}{|l|}{ Mischocyttarus ${ }^{1}$} \\
\hline Clypeopolybia & carbonarius tibialis Richards \\
\hline Haplometrobius & cleomenes Richards, nigroclavatus Zikán \\
\hline Kappa & $\begin{array}{l}\text { deceptus (Fox) (=atrocyaneus Zikán), rufidens (de Saussure) (=immarginatus Richards), } \\
\text { tolensis Richards }\end{array}$ \\
\hline Megacanthopus & collarellus Richards \\
\hline Mischocyttarus & labiatus (Fabricius), melanarius (Cameron) \\
\hline Omega & chalucas Snelling \\
\hline Phi & $\begin{array}{l}\text { angulatus angulatus Richards, basimacula basimacula (Cameron), costaricensis Richards, } \\
\text { mexicanus mexicanus (de Saussure), mixtus Richards, pallidipectus (Smith) }\end{array}$ \\
\hline Scytokeraia & alienus Richards, fraudulentus Richards, mastigophorus Richards, pelor Carpenter \\
\hline \multicolumn{2}{|r|}{ 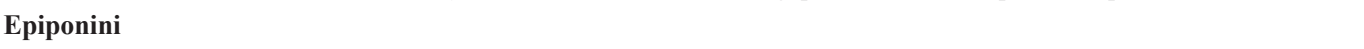 } \\
\hline Agelaia & $\begin{array}{l}\text { angulicollis (Spinola), areata (Say), cajennensis (Fabricius), centralis (Cameron), melanopyga } \\
\text { Cooper, panamaensis (Cameron), pleuralis Cooper, xanthopus melanotica (Richards), yepocapa } \\
\text { (Richards) }\end{array}$ \\
\hline Angiopolybia & zischkai Richards \\
\hline Apoica & pallens (Fabricius), pallida (Olivier), strigata Richards, thoracica du Buysson \\
\hline Brachygastra & $\begin{array}{l}\text { augusti (de Saussure), lecheguana (Latreille), mellifica (Say), scutellaris (Fabricius), } \\
\text { smithii (de Saussure) }\end{array}$ \\
\hline
\end{tabular}


TABLE 1 (Continued)

\begin{tabular}{|c|c|}
\hline $\begin{array}{l}\text { Tribe, Genus, } \\
\text { Subgenus }\end{array}$ & Species \\
\hline Chartergellus & atectus Richards, golfitensis West-Eberhard \\
\hline Charterginus & nevermanni Bequaert \\
\hline Clypearia & naumanni Richards \\
\hline Epipona & guerini (de Saussure), niger (Brèthes) \\
\hline Leipomeles & dorsata (Fabricius) \\
\hline Metapolybia & $\begin{array}{l}\text { azteca Araujo, aztecoides Richards, docilis Richards, mesoamerica Smethurst \& Carpenter, } \\
\text { servilis Cooper }\end{array}$ \\
\hline Nectarinella & championi (Dover) \\
\hline Parachartergus & apicalis (Fabricius), aztecus Willink, fraternus (Gribodo), smithii (de Saussure), \\
\hline \multicolumn{2}{|r|}{$\mathrm{H}^{2}$} \\
\hline Alpha & bifasciata de Saussure \\
\hline Apopolybia & simillima Smith \\
\hline Formicicola & rejecta (Fabricius) \\
\hline Myrapetra & $\begin{array}{l}\text { aequatorialis tristis Bequaert, barbouri Bequaert, belemensis brevitarsus Richards, bistriata } \\
\text { (Fabricius), flavifrons hecuba Richards, nidulatrix Bequaert, occidentalis bohemani Holmgren, } \\
\text { occidentalis nigratella du Buysson, parvulina Richards, plebeja Saussure } \\
\text { (=diguetana du Buysson), scrobalis surinama Richards, selvana Carpenter }\end{array}$ \\
\hline Pedothoeca & emaciata Lucas \\
\hline Trichinothorax & flavitincta Fox, ignobilis (Haliday), raui raui Bequaert, tinctipennis tinctipennis Fox \\
\hline Protopolybia & $\begin{array}{l}\text { acutiscutis (Cameron), chartergoides isthmensis (Richards), collombiana Dos Santos, Silveira \& } \\
\text { Carpenter, exigua binominata (Schulz), exigua exigua (de Saussure), fuscatus (Fox), panamensis } \\
\text { (Zavattari), perfulvula Bequaert, picteti (de Saussure), scutellaris Bequaert, wheeleri Bequaert }\end{array}$ \\
\hline Pseudopolybia & compressa (de Saussure) \\
\hline Synoeca & chalibea de Saussure, septentrionalis Richards \\
\hline
\end{tabular}

1. Subgenera are given for Mischocyttarus and Polybia; all Costa Rican species of Polistes belong to the subgenus Aphanilopterus, which is not indicated.

\section{Key to the Costa Rican Genera of Polistinae}

1. Propodeal orifice dorsally acute, T1 evenly conical in dorsal view (Fig. 1). [Pronotal carina posterior to the fovea (Fig. 2); medium sized to large wasps, WL $>10 \mathrm{~mm}$; nest is an exposed, stalked comb.] ............. Polistes

- Propodeal orifice usually broadly rounded dorsally (Fig. 3). T1 differently shaped: sessile with width greater than

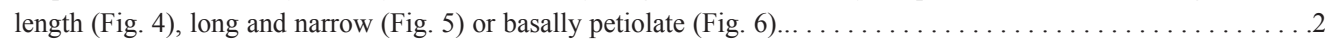

2. Mid and hind tarsus with third and fourth segments asymmetrical, with inner lobe longer than outer lobe (Fig. 7). T1 petiolate: in dorsal view with width half or less that of T2 and at least twice as long as wide (Fig. 8). Nest is an exposed,

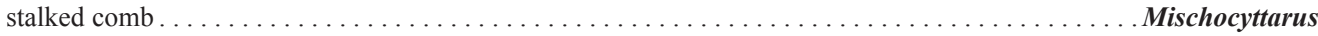

- $\quad$ Mid and hind tarsus with third and fourth segments symmetrical. T1 variously shaped. Nest nearly always covered with

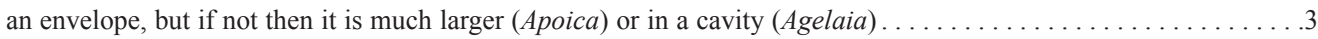

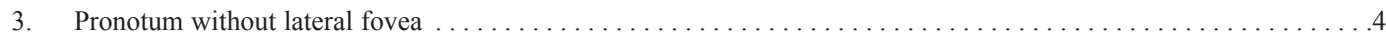

- Pronotum with lateral fovea (Fig. 9), sometimes shallow $\ldots \ldots \ldots \ldots \ldots \ldots \ldots \ldots \ldots \ldots \ldots \ldots \ldots \ldots \ldots$

4. Scutellum angled in profile, metanotum vertical in profile (Fig. 10). Occipital carina present dorsolaterally. [Nest usually very large, $40-50 \mathrm{~cm}$ in diameter. $\ldots \ldots \ldots \ldots \ldots \ldots \ldots \ldots \ldots \ldots \ldots \ldots \ldots \ldots \ldots \ldots$ Brachygastra

- Scutellum rounded in profile, metanotum not vertical in profile, but rather curving anteriorly towards scutellum (Fig.

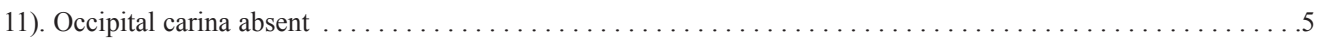

5. Body completely black or blue (except in the rarely collected Synoeca chalibea which is reddish brown ventrally), with virtually no yellow markings. WL 8-20 mm. Nest either hanging from branch, or lying flat on substrate and usually

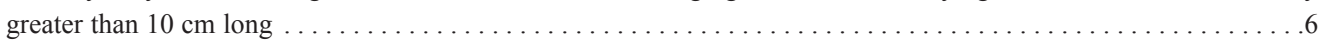


- Body usually with at least some yellow markings. WL usually about 6-8 mm. Nest lying flat on substrate, usually less

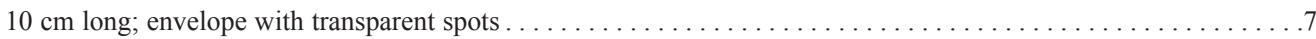

6. Body shining black; WL 8-11mm. Base of fore coxae distended (Fig. 12). Nest usually hanging

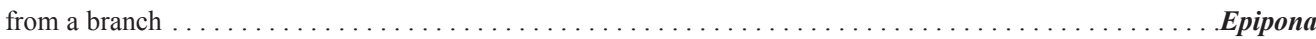

- $\quad$ Body with blue reflections, ranging from completely bluish black to barely a few blusih reflections; WL 17-20 mm. Base of fore coxae not distended. Nest lying flat on substrate $\ldots \ldots \ldots \ldots \ldots \ldots \ldots \ldots \ldots \ldots \ldots$. $\ldots \ldots$. $\ldots \ldots$

7. Body very robust; $\mathrm{T} 1$ short and broad, length $<2 \mathrm{x}$ posterior width. Gena very narrow, $<0.5 \mathrm{x}$ eye width (Fig. 13).

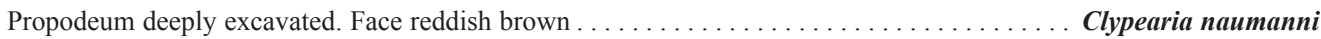

- $\quad$ Body more elongate; T1 very long, length $>3$ x posterior width. Gena $>0.5$ x eye width. Propodeuum not deeply

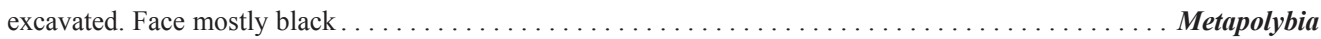

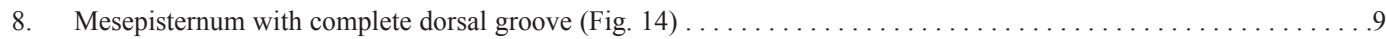

- Mesepisternum with dorsal groove absent or only represented by partial anterior trace $\ldots \ldots \ldots \ldots \ldots \ldots 11$

9. Ocelli enlarged, separated from eyes by less than an ocellar diameter (Fig. 15). Nest a flat, circular comb without an

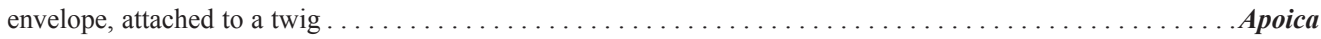

- Ocelli normal, separated from eyes by more than an ocellar diameter. Nest covered with an envelope, or if not, then

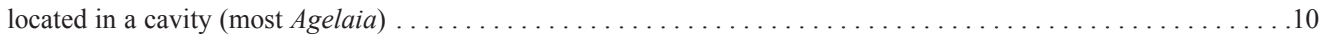

10. Scutum with posterolateral lamella present anteriorly, adjoining tegula (Fig. 16). Very common. Nest often hidden in

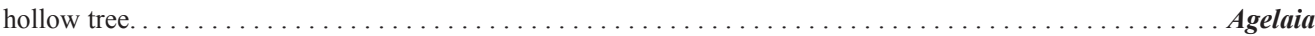

- Scutum with posterolateral lamella absent anteriorly. Uncommon. Nest envelope like an inverted flask. [Body yellow

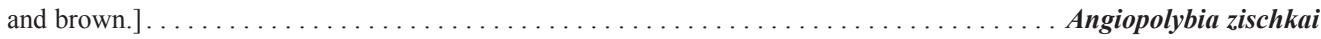

11. Pronotal carina curving sinuously as it runs down the sides (Fig. 17). Fore wing with prestigma about as long as pterostigma (Fig. 18) .

Parachartergus

- Pronotal carina not curving sinuously as it runs down the sides (Fig. 9). Fore wing with prestigma shorter than pteros-

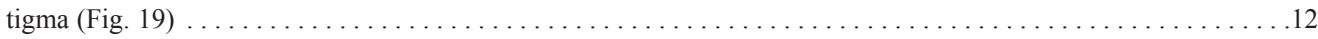

12. Metanotum produced posteromedially into triangular lobe overlapping the anterior propodeum (Fig. 20). [Nest lying

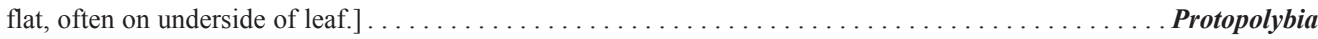

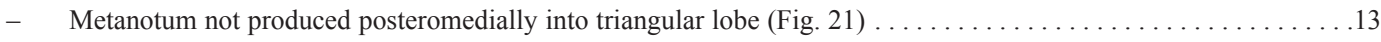

13. T1 with a transverse carina in front of posterior margin (Fig. 22). [Body black and very punctate; width of posterior margin of $\mathrm{T} 1 \approx$ width of $\mathrm{T} 2$; uncommon. $\ldots \ldots \ldots \ldots \ldots \ldots \ldots \ldots \ldots \ldots \ldots \ldots \ldots \ldots \ldots \ldots \ldots \ldots$ Charterginus nevermanni

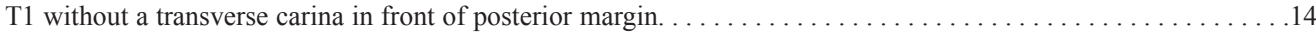

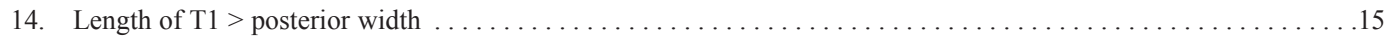

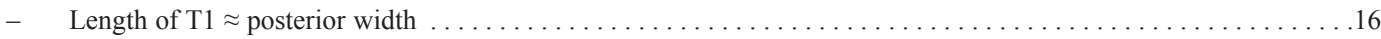

15. Scutum with posterolateral lamella present anteriorly, adjoining tegula (Fig. 16). Body shining, mostly pale yellow and light orangish brown. Minute wasps, ca. $5 \mathrm{~mm}$. Nest flat, often on the undersurface of a leaf . . . Leipomeles dorsata Scutum with posterolateral lamella absent anteriorly (except in P. simillima which is black colored). Body usually less shining, color variable. Often $10 \mathrm{~mm}$ or more. Nest hanging from a branch $\ldots \ldots \ldots \ldots \ldots \ldots \ldots \ldots$ Polybia

16. Body mostly yellow. Scutellum more or less angled in profile, metanotum nearly vertical (Fig. 23). Nest with a single covered comb, flat on substrate. [Small wasps, $\mathrm{WL}=6 \mathrm{~mm}.] \ldots \ldots \ldots \ldots \ldots \ldots \ldots$ Nectarinella championi Body mostly black. Scutellum rounded in profile, metanotum not vertical (as in Fig. 11). Nest with several combs 17

17. Clypeus reddish brown; usually with yellow on the head, posterior margin of pronotum, metanotum, and posterior

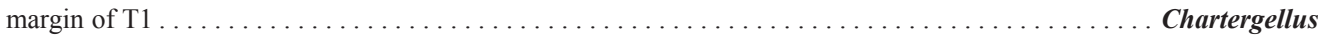
Clypeus mostly black; without yellow on metanotum and $\mathrm{T} 1 \ldots \ldots \ldots \ldots \ldots \ldots \ldots$ Pseudopolybia compressa

\section{Key to species of Polistes}

1. Mesepisternum without evident dorsal groove, but with pronounced epicnemial groove (Fig. 24). [Color mostly black,

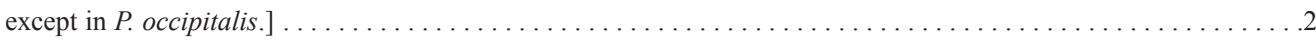
Mesepisternum with evident dorsal groove (Figs. 25-26), though sometimes incomplete (weak in P. aterrimus); epicnemial groove usually absent or weak, but occasionally evident $\ldots \ldots \ldots \ldots \ldots \ldots \ldots \ldots \ldots \ldots \ldots \ldots \ldots \ldots \ldots \ldots \ldots \ldots \ldots$

2. Occipital carina forming a flange on posterior lateral part of head (Fig. 27). Metasoma reddish brown. . P. occipitalis 
- Occipital carina not forming a flange. Metasoma mostly black $\ldots \ldots \ldots \ldots \ldots \ldots \ldots \ldots \ldots \ldots$

3. Occipital carina weak, especially in lower part (Fig. 28). Usually with yellow markings on metanotum, propodeum and

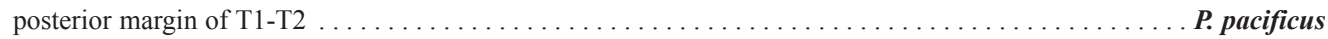

- Occipital carina strong and reaching all the way down to the mandibles (Fig. 29). Propodeum and metasoma usually

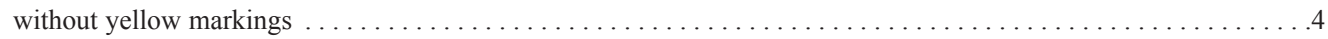

4. T1 (in lateral view) sloping up at an angle of about $70^{\circ}$ (Fig. 30). Lower clypeus reddish brown.

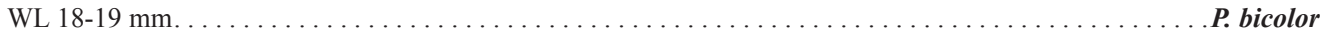

- $\quad$ T1 sloping up more gradually at an angle of about $45^{\circ}$ (Fig. 31). Lower clypeus mostly black.

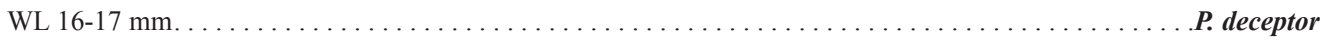

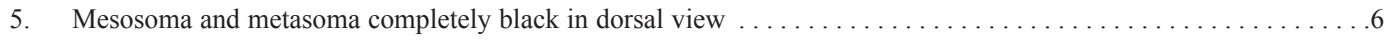

- Mesosoma and metasoma at least with some reddish (or yellowish) brown in dorsal view . . . . . . . . . . . . 9

6. Propodeum with weak striae, not extending to the sides (Fig. 26). [Body black with bluish reflections. Nest is a vertical chain of cells. $] \ldots \ldots \ldots \ldots \ldots \ldots \ldots \ldots \ldots \ldots \ldots \ldots \ldots \ldots \ldots \ldots \ldots \ldots \ldots \ldots \ldots \ldots \ldots \ldots \ldots \ldots \ldots \ldots$

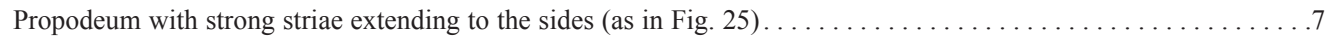

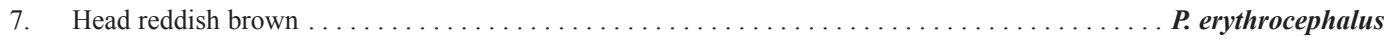

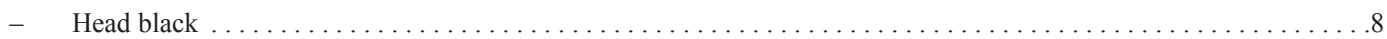

8. Wings reddish brown, paler towards tip. Pronotal carina not strongly protruding at sides. . . . . . . . . P. apicalis Wings dark black. Pronotal carina strongly protruding at sides $\ldots \ldots \ldots \ldots \ldots \ldots \ldots \ldots \ldots \ldots$ aterrimus

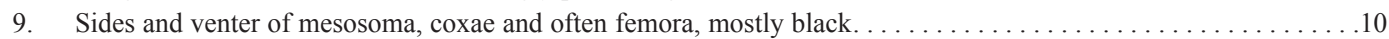

- Sides and venter of mesosoma, and legs, mostly reddish (or yellowish) brown $\ldots \ldots \ldots \ldots \ldots \ldots \ldots$

10. Scutum all black and with erect hairs that are almost as long as the ocelar diameter (Fig. 32) . . . . . .P. oculatus Scutum usually reddish brown, with much shorter hairs $\ldots \ldots \ldots \ldots \ldots \ldots \ldots \ldots \ldots \ldots \ldots \ldots \ldots \ldots$

11. T1 at least as wide posteriorly as long, sloping up almost vertically behind reception of suspensory ligament. Most of antenna, including apex, dark colored on dorsal surface. WL $10-13 \mathrm{~mm} \ldots \ldots \ldots \ldots \ldots \ldots \ldots \ldots$ dorsalis

- $\quad$ T1 usually longer than posterior width and usually not sloping up as steeply. Antenna dark colored on dorsal surface

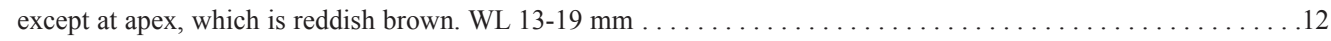

12. Metasomal terga primarily reddish brown, usually with yellow posterior bands. [WL $=14-19 \mathrm{~mm}$. $] \ldots$ P. instabilis

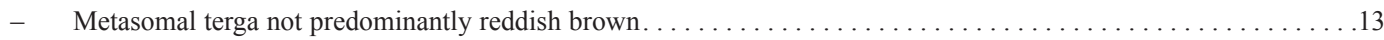

13. Metasomal terga and sterna 2-4 yellow with sinuous dark lines (Figs. 33-34). Yellow stripes on propodeum broad

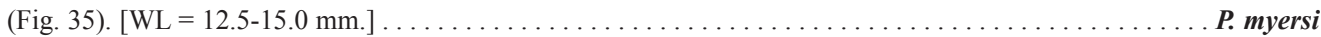

- Metasomal segments 1-4 completely dark, sometimes with light colored spots on terga and on S3 and S4 (Fig. 36). Yellow stripes on propodeum narrow. $[\mathrm{WL}=13-18 \mathrm{~mm}.] \ldots \ldots \ldots \ldots \ldots \ldots \ldots \ldots \ldots \ldots \ldots$ versicolor

14. Propodeum without distinct striae. Mesepisternum with distinct epicnemial groove (Fig. 24). [Body yellowish brown with posterior metasoma dark. $\ldots \ldots \ldots \ldots \ldots \ldots \ldots \ldots \ldots \ldots \ldots \ldots \ldots \ldots \ldots \ldots \ldots \ldots \ldots \ldots$ testaceicolor Propodeum with distinct striae (Fig. 25). Mesepisternum without epicnemial groove or with only a faint groove. .15

15. Scutum reddish brown contrasting with dull yellow propodeum, metasoma with contrasting bands of reddish brown

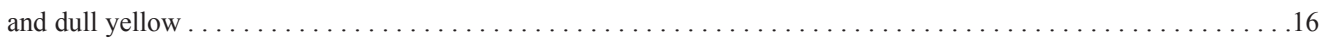

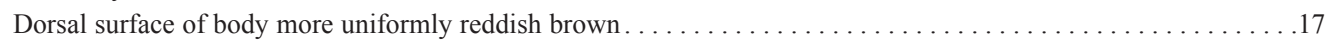

16. Malar space longer than wide (Fig. 37). Propodeal striae almost extending to border with metapleuron (Fig. 25). WL 20-28 mm.

P. carnifex

- Malar space not longer than wide (Fig. 38). Propodeal striae variable, limited to central area or extending to border

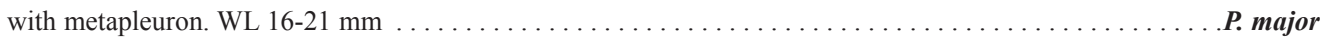

17. Area behind ocelli pale yellow, in contrast to rest of body. Wings yellowish to reddish brown. ......P. infuscatus

- Area behind ocelli reddish brown, like rest of body. Wings darker.

P. canadensis

\section{Key to species of Mischocyttarus}

1. Body black, fore wing black with whitish apex $\ldots \ldots \ldots \ldots \ldots \ldots \ldots \ldots \ldots \ldots \ldots \ldots \ldots \ldots \ldots$ deceptus

- $\quad$ Body black or differently colored, fore wing never black with whitish apex $\ldots \ldots \ldots \ldots \ldots \ldots \ldots \ldots \ldots \ldots \ldots \ldots \ldots$

2. Fore and mid femur with a distinct ventral groove near base, delimiting a small ring (Fig. 39).

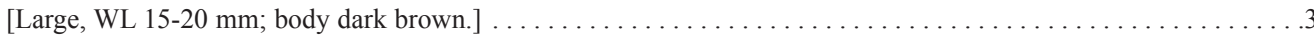


Fore femur without, mid femur rarely with traces of such a groove $\ldots \ldots \ldots \ldots \ldots \ldots \ldots \ldots \ldots \ldots \ldots \ldots \ldots \ldots \ldots \ldots \ldots$

3. T1 about $3 \mathrm{x}$ as long as wide at posterior margin (Fig. 40); tibiae and tarsi yellowish, contrasting with

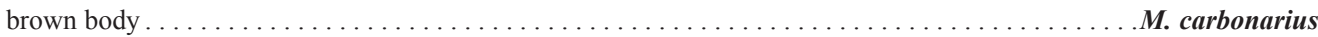

- $\quad$ T1 about 6-7 $\mathrm{x}$ as long as wide at posterior margin (Fig. 41); tibiae and tarsi brown like rest of body. . . . . . . . .4

4. Pronotal keel continuous throughout, central part not concealed by hairs . . . . . . . . . . . . . . M. labiatus

- Pronotal keel weak in center, partially concealed by hairs (especially in dorsal-posterior view). . . . . M. melanarius

5. Pronotum without fovea and sides of mesosoma with extensive yellow or reddish brown $\ldots \ldots \ldots \ldots \ldots$

- $\quad$ Pronotum with fovea (Fig. 42); if fovea weak and difficult to see (M. tolensis) then sides of mesosoma black . . . . .9

6. Lateral and ventral parts of mesosoma, and legs, with extensive reddish brown. Head quite stout in dorsal view, mesosoma extensively punctate $\ldots \ldots \ldots \ldots \ldots \ldots \ldots \ldots \ldots \ldots \ldots \ldots \ldots \ldots \ldots \ldots \ldots \ldots \ldots \ldots \ldots \ldots$

- Mesosoma and legs yellow with black markings, without reddish brown. Head less stout in dorsal view, mesosoma not

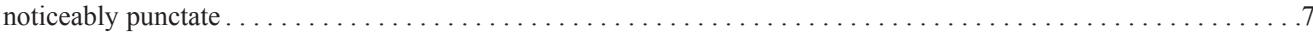

7. Anterior margin of pronotum strongly raised and with 3 "windows" (Fig. 43), this flange visible laterally and ending in a pointed lobe. Pronotal keel curved backward at sides. Male antenna with last segment expanded

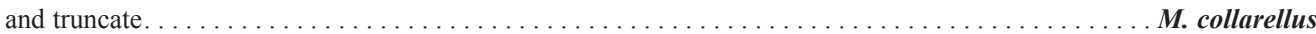

- Anterior margin of pronotum not so strongly raised, without 3 "windows", and not ending in a pointed lobe. Pronotal keel straight in dorsal view. Male antenna with last segment narrow, cylindrical. $\ldots \ldots \ldots \ldots \ldots \ldots \ldots \ldots$

8. Anterior margin of pronotum more strongly raised and followed by a deep furrow with an acute hind margin. Clypeus

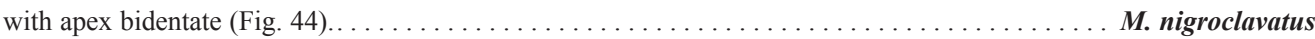

- Anterior margin of pronotum less raised and followed by a shallow furrow with an obtuse hind margin. Clypeus not

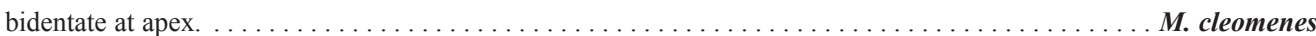

9. Mid tarsus with segment 3 hardly asymmetrical (Fig. 45). [Pronotal carina not forming prominent shoulders.] . . . 10

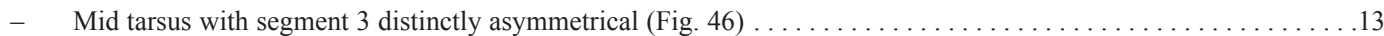

10. WL at least $9.5 \mathrm{~mm}$. Nest with cells more or less perpendicular to the substrate $\ldots \ldots \ldots \ldots \ldots \ldots \ldots$

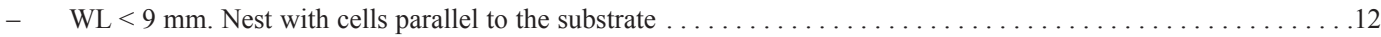

11. Posterior ocelli usually separated by a little less than an ocellar diameter. Male antenna with short, erect bristles beneath. Nest elongate, vertical .

.M. alienus

- Posterior ocelli usually separated by an ocellar diameter. Male antenna without bristles beneath.

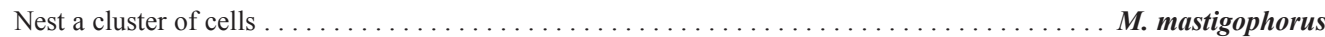

12. Pleuron almost entirely yellow ............... fraudulentus

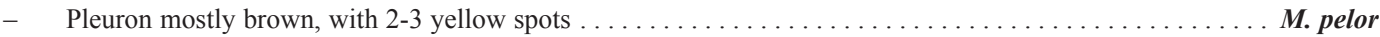

13. Color yellow with black markings, scutum with at least 2 longitudinal yellow lines . . . . . . . . . . . . 14

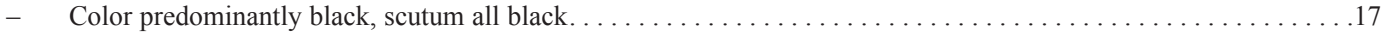

14. $\mathrm{T} 1>3 \mathrm{x}$ as long as posterior width. Metasoma light orangish brown, with yellow posterior bands .... M. angulatus

- $\quad \mathrm{T} 1<3 \mathrm{x}$ as long as posterior width. Metasoma usually dark brown or black, with yellow posterior bands $\ldots \ldots \ldots 15$

15. Pronotal carina weak laterally, not forming a raised shoulder (Fig. 47). S2 usually without clearly differentiated tridentate black spot at base. Mid and hind tibiae and femora usually without sharply contrasting dark stripes.

.M. mexicanus

- Pronotal carina forming a raised shoulder (Fig. 48). S2 usually with clearly differentiated tridentate black spot in anterior half. Mid and hind tibiae and femora usually with sharply contrasting dark stripes

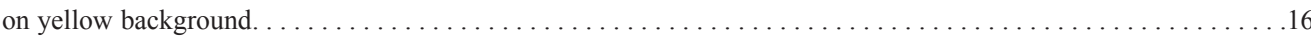

16. Anterior margin of pronotum strongly raised, followed by a deep furrow whose hind margin is acute or lamellate

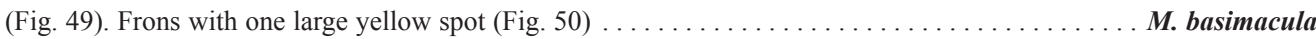

- Anterior margin of pronotum little raised, followed by a feeble furrow whose hind margin is obtuse (Fig. 51). Frons with 3 smaller yellow spots, 1 above and 2 below (Fig. 52), sometimes partially merged. ........ M. costaricensis

17. Dorsal mesosoma and metasoma mostly black, at most with yellow on metanotum and with 2 small

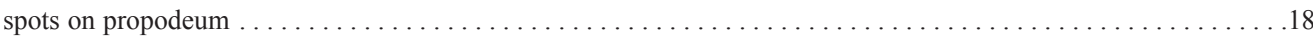
With yellow markings on scutellum, metanotum, propodeum, and posterior part of $\mathrm{T} 1$ (sometimes on posterior

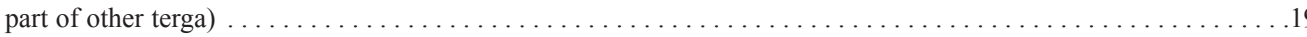

18. Dorsal mesosoma completely black; sides of mesosoma usually with at least some reddish

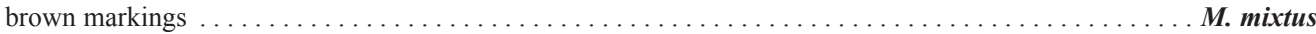

- Metanotum and often propodeum with yellow markings; sides of mesosoma without reddish

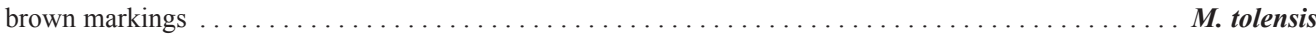


19. Female clypeus mostly orangish brown, apex forming an angle of about $120^{\circ}$. Male face dark; last antennal segment longer than wide

M. rufidens

- Female clypeus mostly black, apex forming an angle of about $90^{\circ}$. Male with entire face (below antennae) yellow; antenna with last 3 segments longer than wide

M. pallidipectus

\section{Key to species of Agelaia}

1. Pronotal carina absent or extremely weak. [Usually yellow colored with black markings; T2-T4 with yellow

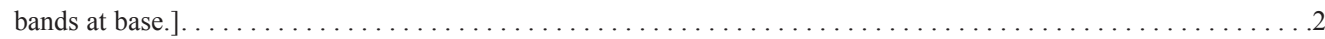

Pronotal carina strong to weak, but always evident (in dorsal view) $\ldots \ldots \ldots \ldots \ldots \ldots \ldots \ldots \ldots \ldots \ldots$

2. Anterior margin of lateral pronotum with a very wide lamella (Fig. 53) .................. pleuralis

- Anterior margin of lateral pronotum with a very narrow lamella (Fig. 54) . . . . . . . . . . . . A. cajennensis

3. Lateral margin of pronotal carina protruding and angular (Fig. 55). Blackish brown, without yellow markings except sometimes on legs. Sides of $\mathrm{T} 1$ divergent posterior to spiracles. WL $12-18 \mathrm{~mm} \ldots \ldots \ldots \ldots \ldots \ldots \ldots \ldots$

- Lateral margin of pronotal carina less protruding and more rounded (Fig. 56). If mostly black colored (A. xanthopus),

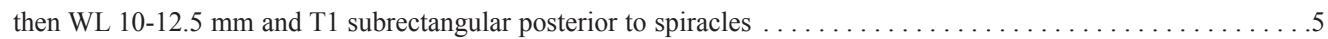

4. Tibiae and tarsi entirely yellow $\ldots \ldots \ldots \ldots \ldots \ldots \ldots \ldots \ldots \ldots \ldots \ldots \ldots \ldots \ldots \ldots \ldots \ldots \ldots \ldots \ldots \ldots$ angulicolis

- Tibiae and tarsi black or blackish brown, fore and mid tibiae sometimes with a yellowish stripe in males. . . . . . panamaensis

5. Pronotal carina very strongly raised in front of fovea, curving around it and fading as it curves, leaving the fovea at the bottom of a deep hollow (Fig. 57). Body blackish brown, usually without or with

very few yellow markings $\ldots \ldots \ldots \ldots \ldots \ldots \ldots \ldots \ldots \ldots \ldots \ldots \ldots \ldots \ldots \ldots \ldots \ldots \ldots \ldots \ldots \ldots \ldots$

- $\quad$ Pronotal carina not very strongly raised in front of fovea. Body usually with more yellow markings $\ldots \ldots \ldots \ldots 6$

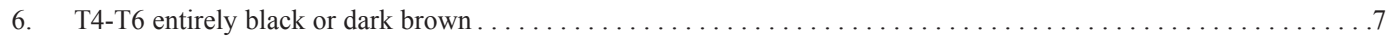

- T4-T6 with yellow posterior bands, or metasoma mostly brownish orange $\ldots \ldots \ldots \ldots \ldots \ldots \ldots \ldots \ldots \ldots \ldots \ldots$

7. Eyes with short hairs. T1-T3 usually dark colored (with yellow bands), sides of T1 dark. ... A. yepocapa (in part)

- $\quad$ Eyes without or with very few short hairs. T1-T3 light brown (with yellow bands), sides of T1

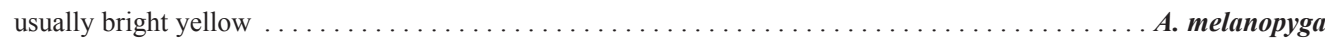

8. All terga brownish orange (posterior terga sometimes darker), without or with very narrow, almost inconspicuous

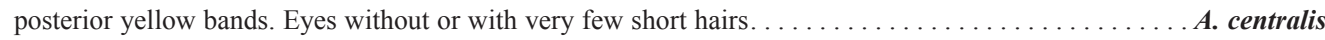

- $\quad$ Terga black or dark brown, at least T2-T3 with conspicous yellow bands. Eyes with short hairs $\ldots \ldots \ldots \ldots \ldots .9$

9. Dorsal pronotal carina more raised at sides. T1 subquadrate behind spiracles in workers and males (Fig. 58), subsessile in queens. Yellow bands on terga about $1 / 4$ to $1 / 3$ as broad as the tergum . . . . . . . . . . . . . A areata

- Dorsal pronotal carina less raised at sides. T1 longer, subrectangular or with sides divergent after spiracles (Fig. 59). Yellow bands on terga about $1 / 6$ to $1 / 5$ as broad as the tergum. . . . . . yepocapa (in part)

\section{Key to species of Apoica}

1. Metasoma light brown with pale posterior bands on some terga $\ldots \ldots \ldots \ldots \ldots \ldots \ldots \ldots \ldots \ldots \ldots$ strigata

- Metasoma uniformly colored, without transverse bands on dorsal surface $\ldots \ldots \ldots \ldots \ldots \ldots \ldots \ldots \ldots \ldots$

2. Dorsal surface of metasoma entirely pale yellow to white $\ldots \ldots \ldots \ldots \ldots \ldots \ldots \ldots \ldots \ldots \ldots \ldots$. pallens

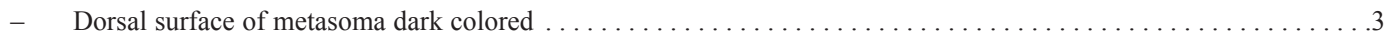

3. Last metasomal tergum entirely pale or with pale colored triangle (Fig. 60). Eye with prominent hairs present over

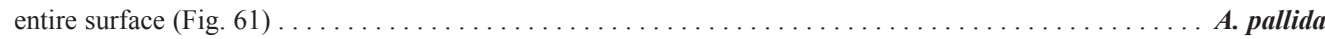
Last metasomal tergum rarely with strong pale color, occasionally with faint pale color on posterior tip of tergum, but not triangle-shaped. Eye bare or with just a few hairs.

A. thoracica* $^{*}$

* A. ellenae from Barro Colorado Island, Panama, is similar to A. thoracica, but has a fine pubescence that generates a silvery-gray sheen over the meso- and metasoma. 


\section{Key to species of Brachygastra}

1. Top of head and scutum with yellow markings $\ldots \ldots \ldots \ldots \ldots \ldots \ldots \ldots \ldots \ldots \ldots \ldots \ldots \ldots \ldots \ldots \ldots$ smithii

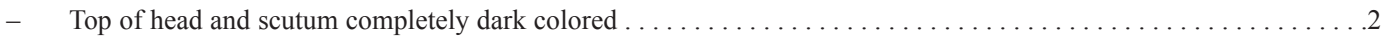

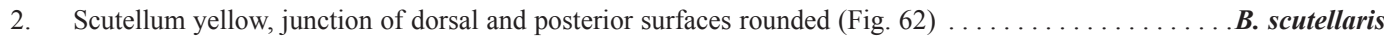

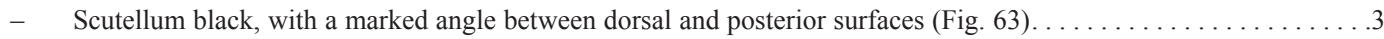

3. Head and mesosoma without golden pubescence, wings transparent. Mesosoma coarsely punctured.

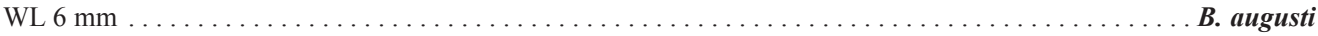

- Head and mesosoma with golden pubescence, wings yellowish orange and with dark tips. Mesosoma less coarsely

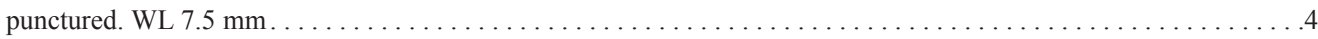

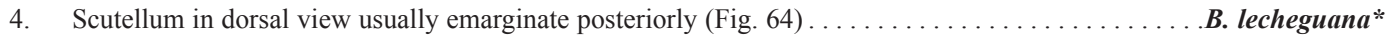

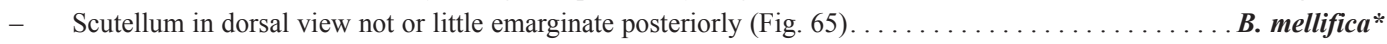

* The only reliable way of separating B. lecheguana from B. mellifica is on the basis of the male genitalia (Naumann, 1968).

\section{Key to species of Chartergellus}

- $\quad$ Frons with 3-pointed reddish brown mark, with the central point nearly reaching the median ocellus (Fig. 66); area immediately above mandible predominantly whitish.

C. golfitensis

- Frons with reddish brown mark that is not 3-pointed, dorsal central part usually closer to antennal insertion than to median ocellus (Fig. 67); area immediately above mandible black.

C. atectus

\section{Key to species of Epipona}

- $\quad$ Propodeum with dense punctures, only slightly concave in center and this area not bordered by distinct carina.

E. guerini

Propodeum with fewer punctures, especially in the anterodorsal area; center of propodeum very concave and this area bordered laterally by a distinct carina

E. niger

\section{Key to species of Metapolybia}

1. Propodeum with numerous erect hairs which are at least as long as maximum width of propodeal orifice (Fig. 68); median groove distinct in posterior part of propodeum. Gena not or scarcely narrowed toward base

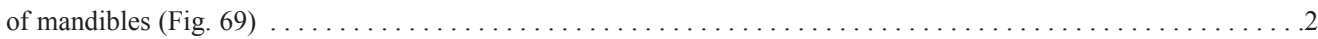

- Propodeum with sparse short hairs, shorter than maximum width of propodeal orifice; median groove indistinct.

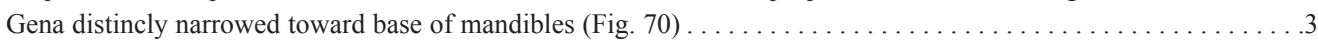

2- Humerus obtusely projecting in front of tegula. Anterolateral carina of pronotum relatively more acute.

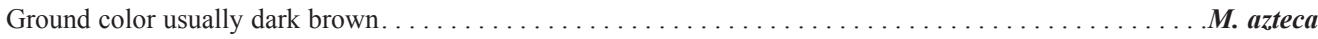

- Humerus hardly projecting at all. Anterolateral carina of pronotum obtuse. Ground color usually reddish brown $\ldots \ldots \ldots \ldots \ldots \ldots \ldots \ldots \ldots \ldots \ldots \ldots \ldots \ldots \ldots \ldots \ldots \ldots \ldots \ldots \ldots \ldots \ldots \ldots \ldots \ldots \ldots \ldots$

3. Anterolateral carina of pronotum sharp-edged; humerus bluntly projecting in front of tegula (Fig. 71).

Just T1 or T1-T2 with yellow posterior bands $\ldots \ldots \ldots \ldots \ldots \ldots \ldots \ldots \ldots \ldots \ldots \ldots \ldots \ldots \ldots$ aztecoides

- $\quad$ Anterolateral carina of pronotum rounded; humerus not noticeable. T1-T3 and often T4-T5

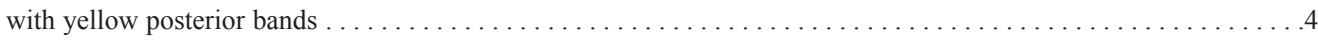

4. Propodeum with very weak, fine striae. Propodeum entirely black or with small amount of yellow. ......M. docilis

- Propodeum without striae. Usually with a pair of light colored spots on posterior edge of propodeum (on each side of propodeal orifice).

M. servilis 


\section{Key to species of Parachartergus}

1. Ground color yellowish brown; wings transparent, yellowish $\ldots \ldots \ldots \ldots \ldots \ldots \ldots \ldots \ldots \ldots \ldots \ldots$ smithii

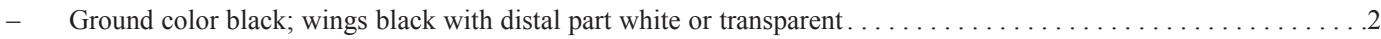

2. Dorsal surface of head and mesosoma with almost no erect hairs. Propodeum in dorsal view quadrate

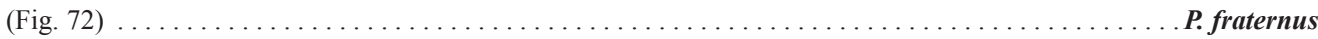

- Dorsal surface of head and mesosoma with numerous erect hairs. Propodeum in dorsal view with sides converging

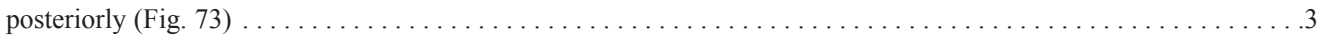

3. Pronotal carina where it passes down the sides distinctly curved (Fig. 74). WL $=12-13 \mathrm{~mm} \ldots \ldots \ldots$. . P. apicalis

- Pronotal carina where it passes down the sides barely curved (Fig. 75). WL $=10-11 \mathrm{~mm}$

P. aztecus

\section{Key to species of Polybia}

1. Predominanly light orangish brown, or with extensive yellow markings; sides of mesosoma and coxae

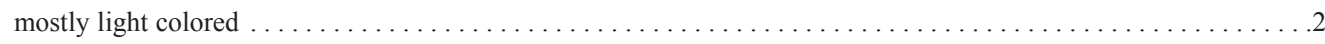

Predominantly black or dark brown, including sides of mesosoma and coxae; if yellow markings are present,

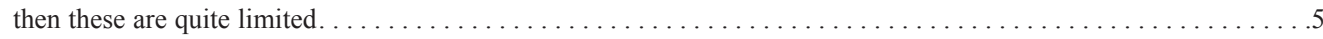

2. Scutum with short erect hairs, their length equal to about half the diameter of the ocellus (Fig. 76).

Metasoma black with yellow bands $\ldots \ldots \ldots \ldots \ldots \ldots \ldots \ldots \ldots \ldots \ldots \ldots \ldots \ldots \ldots \ldots \ldots \ldots \ldots \ldots \ldots$

- Scutum without erect hairs, or hairs much shorter. Metasoma generally orangish brown with yellow bands . . . . . . 3

3. Length of T1 about $2 \mathrm{x}$ posterior width (Fig. 77). Propodeum with central groove that widens posteriorly.

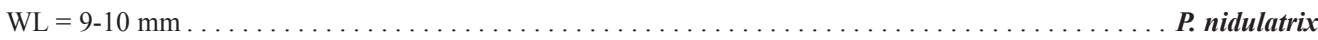

- $\quad$ Length of T1 $>2 \times$ posterior width (Figs. 78-79). Propodeum without evident central groove,

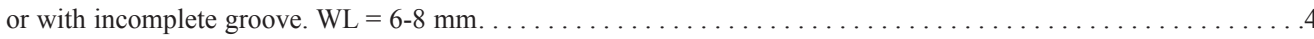

4. T1 with spiracular area barely or not projecting, not forming a concavity behind spiracle (Fig. 78).

Pronotum without trace of carina. Color usually light brown $\ldots \ldots \ldots \ldots \ldots \ldots \ldots \ldots \ldots \ldots \ldots$. bistriata

- $\quad$ T1 with spiracular area clearly projecting and forming a small concavity right behind spiracle (Fig. 79).

Pronotum with slight trace of dorsal carina. Color paler, predominantly yellowish $\ldots \ldots \ldots \ldots \ldots \ldots$ selvana

5. Fore wing with anterior margin orangish brown, black at tip $\ldots \ldots \ldots \ldots \ldots \ldots \ldots \ldots \ldots \ldots \ldots$

- $\quad$ Fore wing variable in color, if anterior margin orangish brown (P. flavitincta) then without black tip .........6

6. Propodeum with punctures and/or scutum with erect hairs about as long as half the diameter of the ocellus.

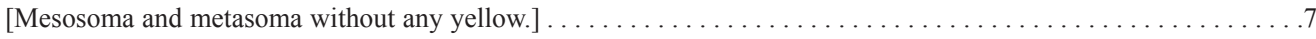

Propodeum without punctures, scutum without erect hairs or hairs much shorter $\ldots \ldots \ldots \ldots \ldots \ldots \ldots \ldots 11$

7. Scutum without erect hairs. $\mathrm{T} 1<1.4 \mathrm{x}$ as long as posteriorly wide $\ldots \ldots \ldots \ldots \ldots \ldots \ldots \ldots \ldots \ldots$ simillima

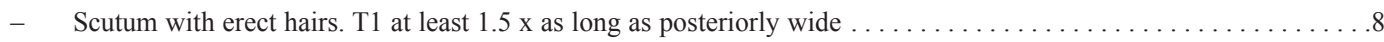

8. Pronotal carina absent or very weak. Larger than most other Polybia, WL at least $12 \mathrm{~mm} \ldots \ldots$..... P. flavitincta

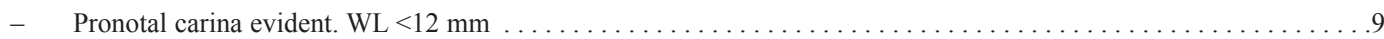

9. $\mathrm{T} 1$ with numerous distinct punctures and $>2 \mathrm{x}$ as long as posteriorly wide $\ldots \ldots \ldots \ldots \ldots$ tinctipennis

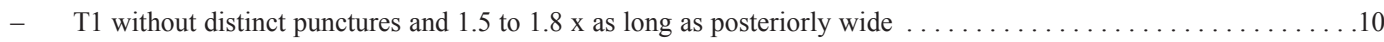

10. Head and mesosoma with very dense fine sculpture, without any shining surface. Basal cell of fore wing blackened throughout (Fig. 80). Anterior central propodeum with much denser hairs than rest of propodeum ...... P. ignobilis Head and mesosoma finely reticulate, but somewhat shining. Basal cell blackened primarily at apex (Fig. 81).

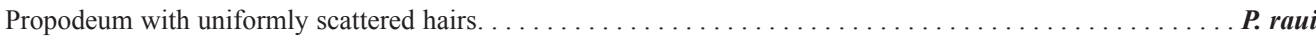

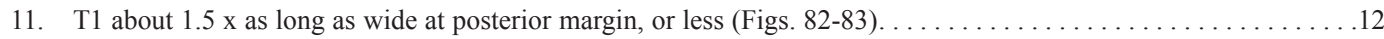

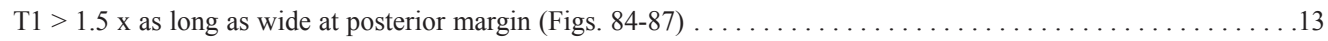

12. Body all black. Propodeal valvula narrow and almost parallel-sided (Fig. 88). . . . . . . . . . . .P. bifasciata

- Metanotum and propodeum with yellow. Propodeal valvula broadly triangular (Fig. 89) . . . . . . . . P. barbouri

13. Eyes with scattered short hairs. All black except pale markings on posterior edge of pronotum and posterior edge of $\mathrm{T} 1$, rarely with more pale markings. [Body long and narrow; found only above $1000 \mathrm{~m}.] \ldots \ldots$.... aequatorialis Eyes bare, but if with a few short hairs then body often with more yellow markings $\ldots \ldots \ldots \ldots \ldots \ldots \ldots$ 
14. Scrobal furrow (vertical groove on upper mesepisternum, as in Fig. 25) deep and complete, though sometimes shallower in lower part. T1 $1.8 \mathrm{x}$ as long as wide at posterior margin (Fig. 87). [With yellow on clypeus, propodeum, and posterior bands on T1-T2; usually with yellow also on scutellum and metanotum. Propodeum with erect hairs that are nearly as long as maximum width of propodeal orifice (Fig. 90).] .

P. occidentalis

- Scrobal furrow usually shallow and incomplete (very faint in lower part). T1 at least $2 \mathrm{x}$ as long as wide at posterior margin (Figs. 85-86), except in P. scrobalis which usually has fewer yellow markings

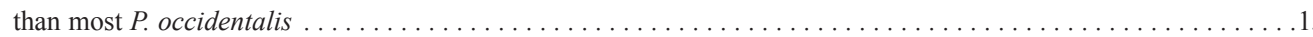

15. Propodeum with erect hairs that are nearly as long as maximum width of propodeal orifice (as in Fig. 90).

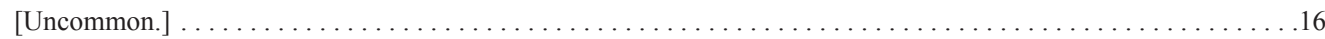

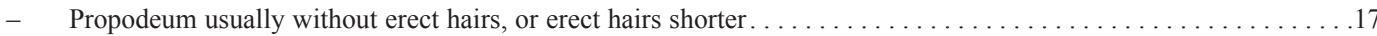

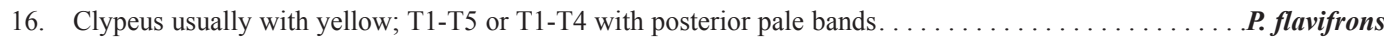

- Clypeus usually all black (rarely with 2 pale spots); metasoma with posterior pale band only on T1, rarely

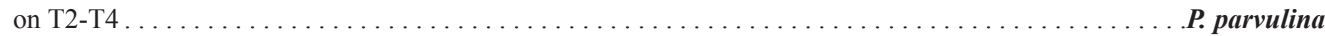

17. T1 $1.8 \mathrm{x}$ longer than wide at posterior margin (Fig. 84). [Mostly all black, with yellow posterior

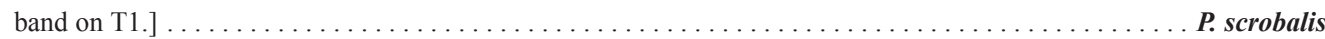

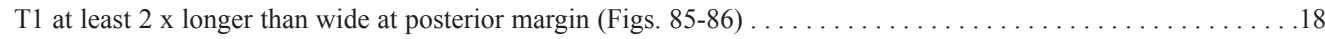

$18 \mathrm{~T} 1$ very narrow anteriorly, with posterior width nearly $3 \mathrm{x}$ anterior width (Fig. 86)........... belemensis

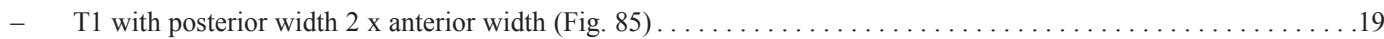

19 Occipital carina visible for most of its length behind eyes, extending up to level of

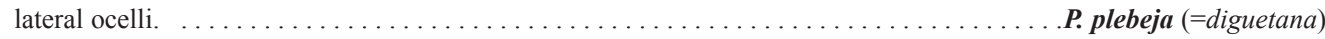

- Occipital carina weak, not reaching above top of foramen magnum. undescribed species

\section{Key to species of Protopolybia}

1. Scutum with erect hairs, the latter about as long as maximum width of antenna $\ldots \ldots \ldots \ldots \ldots \ldots \ldots$

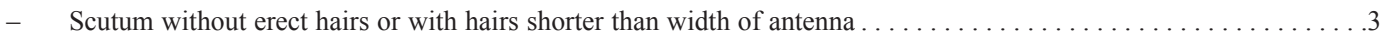

2. Anterior lateral margins of pronotum prominently pointed (Fig. 91); scutum with longitudinal yellow stripes; T2 usually with 3 elongate yellow spots (in addition to posterior band; Fig. 92) . . . . . . . . . P. wheeleri

- Anterior lateral margins of pronotum rounded and less prominent (Fig. 93); scutum all black; T2 usually with 2 yellow spots (in addition to posterior band) $\ldots \ldots \ldots \ldots \ldots \ldots \ldots \ldots \ldots \ldots \ldots \ldots \ldots \ldots \ldots \ldots \ldots \ldots$

3. Gena about two thirds as wide as eye at ocular emargination, or narrower (Figs. 94-95). Scrobal furrow (vertical groove on upper mesepisternum, as in Fig. 25) very weak. Propodeum usually without yellow

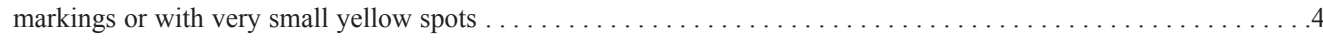

- Gena about three fourths as wide as eye at ocular emargination, or about as wide as eye (Fig. 96).

Scrobal furrow distinct. Propodeum usually with yellow markings $\ldots \ldots \ldots \ldots \ldots \ldots \ldots \ldots \ldots \ldots \ldots$

4. Occipital carina extending less than half way down head (Fig. 94). Mesosoma and metasoma completely black.

- Occipital carina extending more than half way down head (Fig. 95). Mesosoma and metasoma

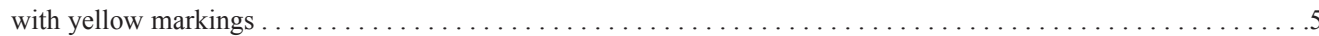

5. Lateral part of pronotal carina forming an angular projection. Tip of metanotum more rounded (Fig. 97). Angles of propodeum more projecting. . $\ldots \ldots \ldots \ldots \ldots \ldots \ldots \ldots \ldots \ldots \ldots \ldots \ldots \ldots \ldots \ldots$ chartergoides

- $\quad$ Lateral part of pronotal carina weak and rounded. Tip of metanotum more pointed (Fig. 98).

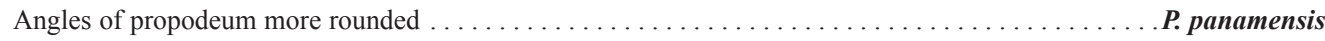

6. Top of head and mesosoma shining (between punctures). Gena as wide as eye; occipital carina evident and extending to base of mandibles. Body orangish brown with yellow markings. . . . . . . . perfulvula Top of head and mesosoma not shining, matte. Gena narrower than eye, occipital carina usually less evident.

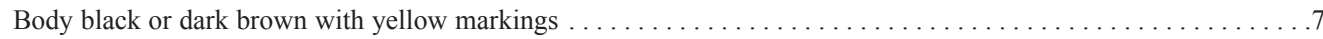

7. Base of $\mathrm{T} 1$ notably widened, with a triangular projection on each side. Usually with yellow immediately in front of anterior ocellus $\ldots \ldots \ldots \ldots \ldots \ldots \ldots \ldots \ldots \ldots \ldots \ldots \ldots \ldots \ldots \ldots \ldots \ldots \ldots \ldots \ldots \ldots \ldots \ldots$

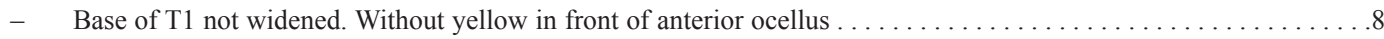


8. Length of $\mathrm{T} 1$ about equal to posterior width. Posterior propodeum shallowly concave, without evident groove.

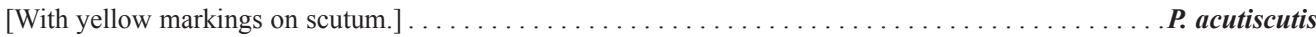

- $\quad$ T1 longer than posterior width. Posterior propodeum wih a narrow groove in center $\ldots \ldots \ldots \ldots \ldots$

9. T2 with anterior yellow band or two large yellow spots. [Uncommon.] $\ldots \ldots \ldots \ldots \ldots \ldots \ldots \ldots \ldots$

- T2 dark anteriorly, with at most small spots $\ldots \ldots \ldots \ldots \ldots \ldots \ldots \ldots \ldots \ldots \ldots \ldots \ldots \ldots \ldots \ldots \ldots$

\section{Key to species of Synoeca}

- Malar space shorter than antennal pedicel (Fig. 99). Propodeum with fine punctation throughout. Wings yellowish to brownish, darker anteriorly; body pale reddish brown ventrally, dark dorsally, with slight bluish reflections.

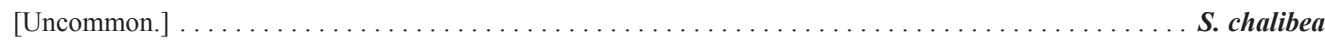

- Malar space about as long as antennal pedicel (Fig. 100). Lateral part of propodeum with sparse faint punctation. Wings dark throughout; body bluish to blackish $\ldots \ldots \ldots \ldots \ldots \ldots \ldots \ldots \ldots \ldots \ldots \ldots \ldots \ldots$ Septentrionalis

Ethical statement: authors declare that they all agree with this publication and made significant contributions; that there is no conflict of interest of any kind; and that we followed all pertinent ethical and legal procedures and requirements. All financial sources are fully and clearly stated in the acknowledgements section. A signed document has been filed in the journal archives.

\section{ACKNOWLEDGEMENTS}

We would like to thank the staff of the American Museum of Natural History, the Zoology Museum of the University of Costa Rica, and the National Museum of Costa Rica (formerly INBio) for access to specimens. We are also grateful to three anonymous reviewers for improving the manuscript.

\section{RESUMEN}

Claves taxonómicas para las especies de avispas eusociales de Costa Rica (Hymenoptera: Vespidae: Polistinae). Las avispas de la subfamilia Polistinae son uno de los cuatro grupos principales de insectos eusociales en el neotrópico, y son de importancia económica tanto por sus picaduras como por su papel en control biológico. Sin embargo, no existen claves actualizadas para la identificación de las especies de América Central. Aquí se proveen claves ilustradas para los 18 géneros y las 106 especies conocidas de Costa Rica y se incluyen cien dibujos originales.
Palabras claves: Polistinae; avispas sociales; identificación; claves taxonómicas.

\section{REFERENCES}

Carpenter, J. M. (1999). Taxonomic notes on paper wasps (Hymenoptera: Vespidae; Polistinae). American Museum Novitates, 3259, 1-44.

Carpenter, J. M. (2012). Notes on types of some American wasps in the Spinola collection. Entomologica Americana, 117, 121-126.

Carpenter, J. M., \& Kojima, J. -I. (2002). A new species of paper wasp from Costa Rica (Hymenoptera: Vespidae; Polistinae, Epiponini). Journal of the New York Entomological Society, 110, 212-223.

Carpenter, J. M., \& Wenzel, J. W. (1988). A new species and nest type of Mischocyttarus from Costa Rica (Hymenoptera: Vespidae; Polistinae), with descriptions of nests of three related species. Psyche, 95, 89-99.

Cooper, M. (1999). New species of Metapolybia Ducke (Hym., Vespidae, Polistinae). Entomologists 'Monthly Magazine, 135, 107-110.

Cooper, M. (2000). Five new species of Agelaia Lepeletier (Hym., Vespidae, Polistinae) with a key to members of the genus, new synonymy and notes. Entomologists' Monthly Magazine, 136, 177-198.

Dos Santos Junior, J. N. A., Silveira, O. T., \& Carpenter, J. M. (2015). Phylogeny of Protopolybia Ducke, 1905 and taxonomic revision of the Protopolybia exigua species-group (Hymenoptera: Vespidae, Polistinae), with description of four new species. Zootaxa, 3956, 151-182. 
Naumann, M. G. (1968). A revision of the genus Brachygastra (Hymenoptera, Vespidae). University of Kansas Science Bulletin, 47, 929-1003.

Richards, O. W. (1978). The social wasps of the Americas excluding the Vespinae. London: British Museum (Natural History).

Silveira, O. T. (2006). Revision of the subgenus Kappa de Saussure of Mischocyttarus de Saussure (Hym.; Vespidae, Polistinae, Mischocyttarini). Zootaxa, 1321, $1-108$.

Silveira, O. T., Silva, S. S., \& Felizardo, S. P. S. (2015). Notes on social wasps of the group of Mischocyttarus (Omega) punctatus (Ducke), with description of six new species (Hymenoptera, Vespidae, Polistinae). Revista Brasileira de Entomologia, 59, 154-168.

Smethurst, M. E., \& Carpenter, J. M. (1997). A new species of Metapolybia Ducke from Central America (Hymenoptera: Vespidae; Polistinae). Journal of the New York Entomological Society, 105(3-4), 180-185.
Snelling, R. R. (1983). Taxonomic and nomenclatural studies on American polistine wasps (Hymenoptera: Vespidae). Pan-Pacific Entomologist, 59, 267-280.

Wenzel, J. W. (1998). A generic key to the nests of hornets, yellowjackets, and paper wasps worldwide (Vespide: Vespinae, Polistinae). American Museum Novitates, $3224,1-39$.

West-Eberhard, M. J., Carpenter, J. M., Gelin, L. F. F., \& Noll, F. B. (2010). Chartergellus golfitensis WestEberhard: a new species of Neotropical swarm-founding wasp (Hymenoptera: Vespidae, Polistinae) with notes on the taxonomy of Chartergellus zonatus Spinola. Journal of Hymenoptera Research, 19, 84-93.

West-Eberhard, M. J., Carpenter, J. M., \& Hanson, P. E. (2006). Familia Vespidae. In P. E. Hanson \& I. D. Gauld (Eds.), Hymenoptera de la Región Neotropical. Memoirs of the American Entomological Institute, $77,617-644$. 
1

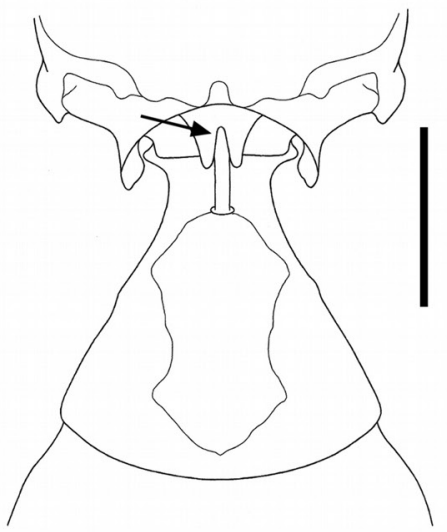

2

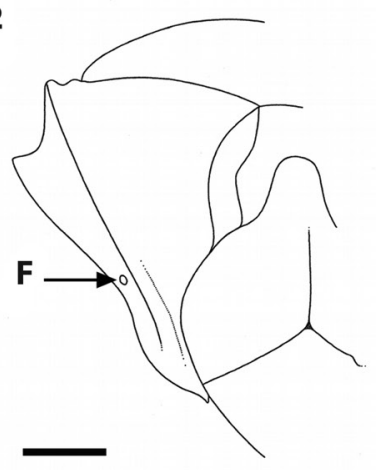

4

3

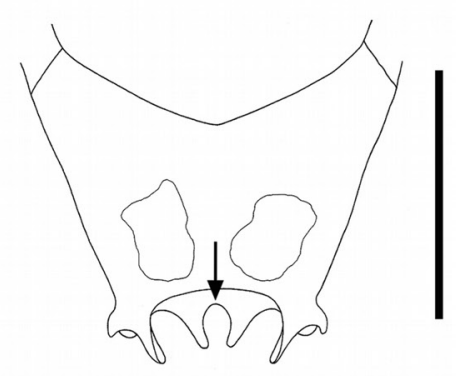

7

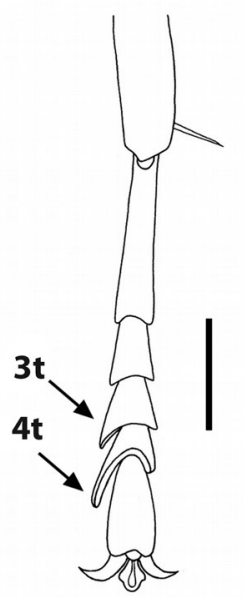

8

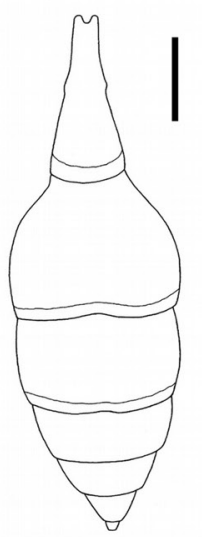

5

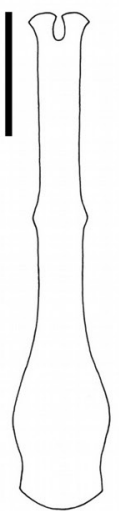

6

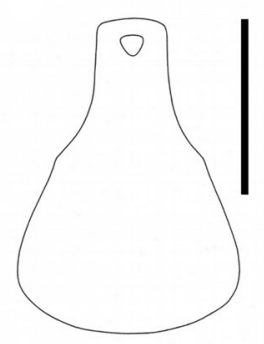

9

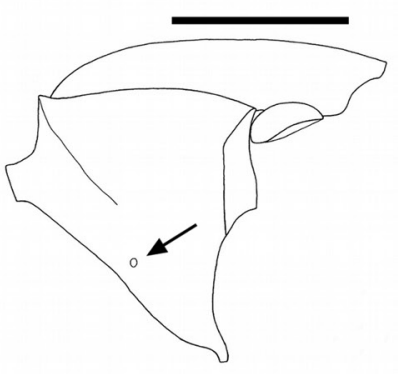

Figs. 1-9. Polistinae genera. 1. Polistes dorsalis propodeal orifice (arrow), dorsal view, followed by first metasomal tergum. 2. P. erythrocephalus pronotum, lateral view ( $\mathrm{F}=$ fovea). 3. Polybia occidentalis propodeal orifice (arrow), dorsal view. 4-6. First metasomal tergum, dorsal view, of Protopolybia acutiscutis (4), Mischocyttarus melanarius (5) and Polybia barbouri (6). 7. Mischocyttarus basimacula third (3t) and fourth segment (4t) of middle tarsus, dorsal view. 8. M. fraudulentus metasoma, dorsal view. 9. Polybia rejecta pronotum, lateral view, showing fovea (arrow). 

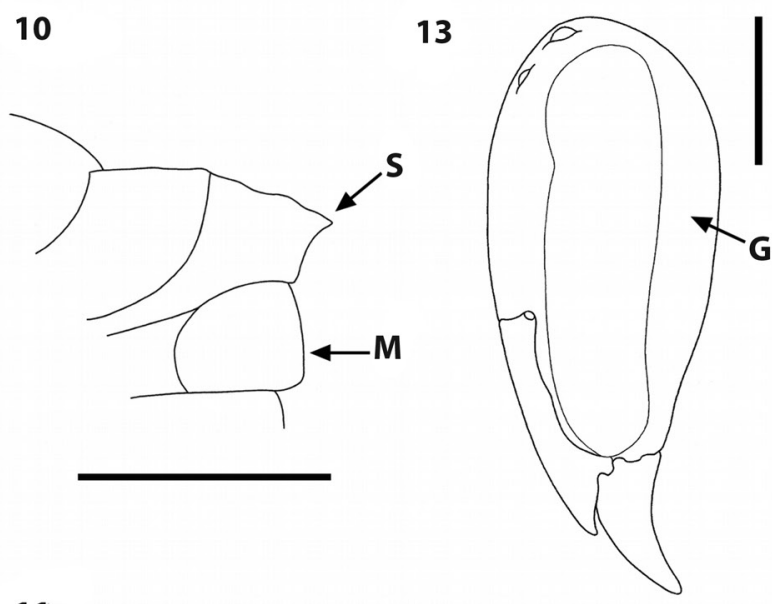

11
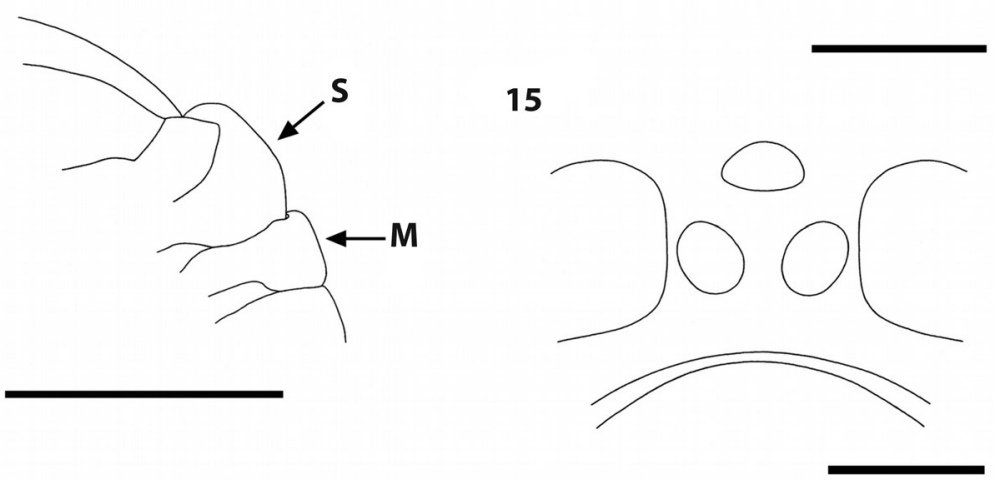

12

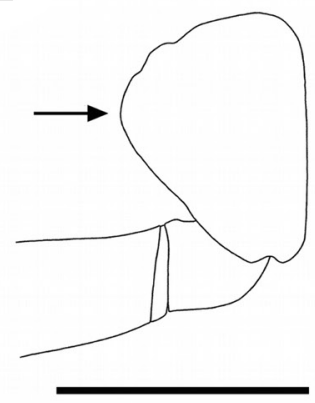

16

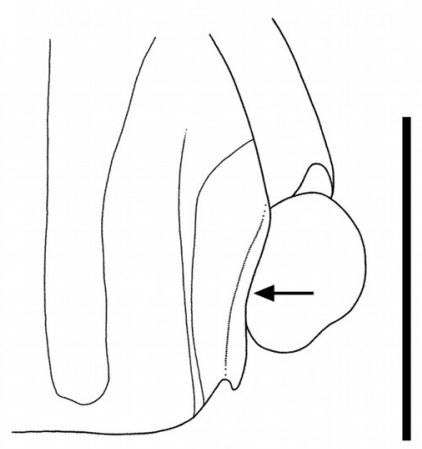

Figs. 10-16. Polistinae genera. 10-11. Posterior edge of scutellum (S) and metanotum (M), lateral view, of Brachygastra mellifica (10) and Metapolybia aztecoides (11). 12. Epipona guerini fore coxa, anteroventral view. 13. Clypearia naumanni gena (G), lateral view. 14. Agelaia melanopyga mesepisternum dorsal groove (arrow), lateral view. 15. Apoica pallens ocelli, dorsal view. 16. Agelaia centralis posterolateral lamella on scutum (arrow), dorsal view. 
17

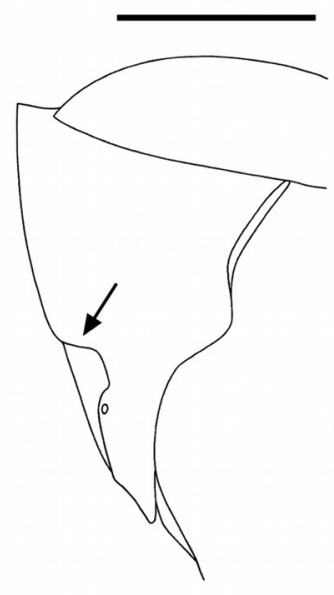

20

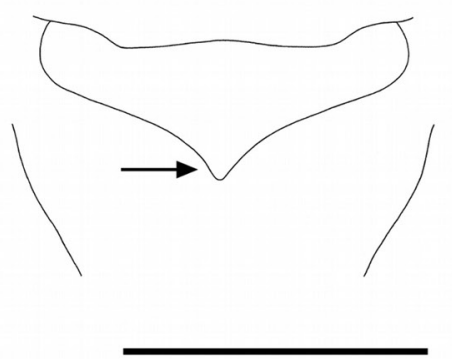

22

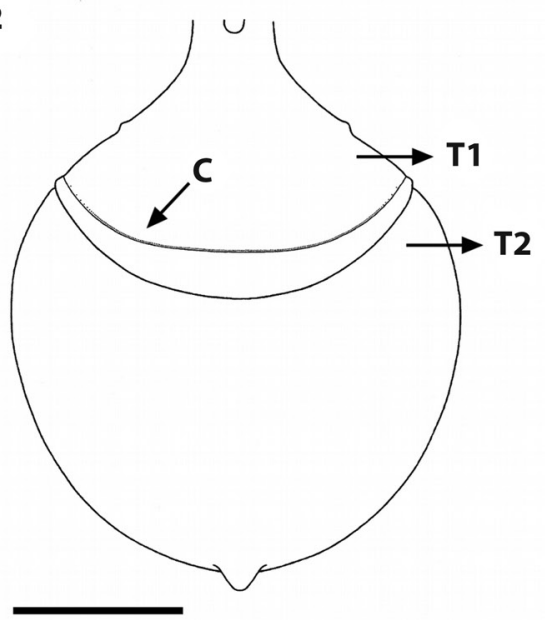

18

19
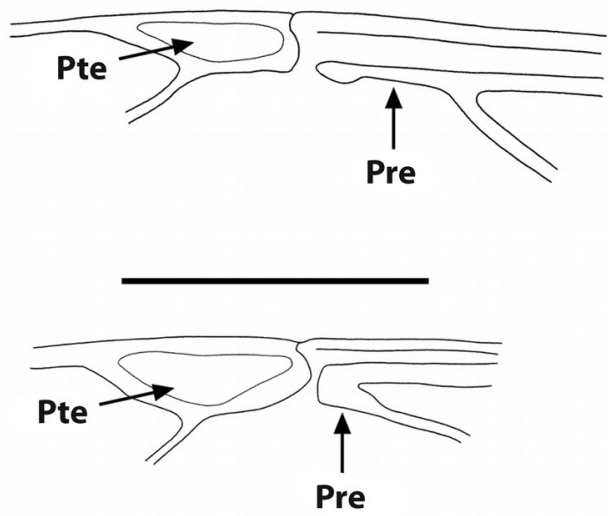

21

\section{3}

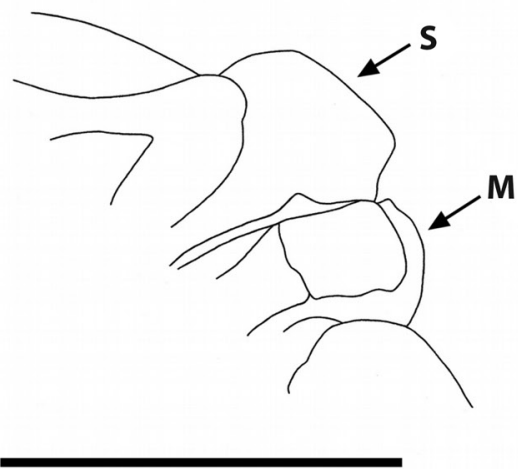

Figs. 17-23. Polistinae genera. 17. Parachartergus apicalis curved pronotal carina, lateral view. 18-19. Relative length of prestigma (Pre) vs pterostigma (Pte) in P. fraternus (18) and Charterginus nevermanni (19). 20. Protopolybia panamensis metanotum with a posteromedial lobe, posterodorsal view. 21. Polybia parvulina metanotum without posteromedial lobe, posterodorsal view. 22. Charterginus nevermanni transverse carina (C) in front line separating the first (T1) and second metasomal terga (T2), dorsal view. 23. Nectarinella championi posterior edge of scutellum (S) and metanotum (M), lateral view. 
24

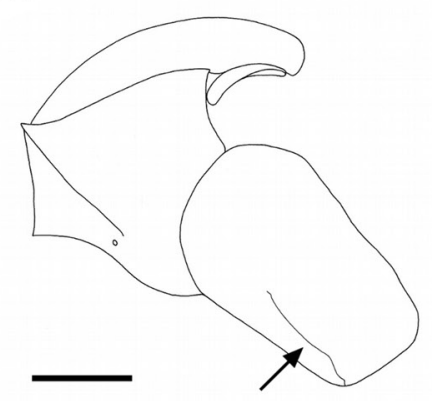

\section{5}

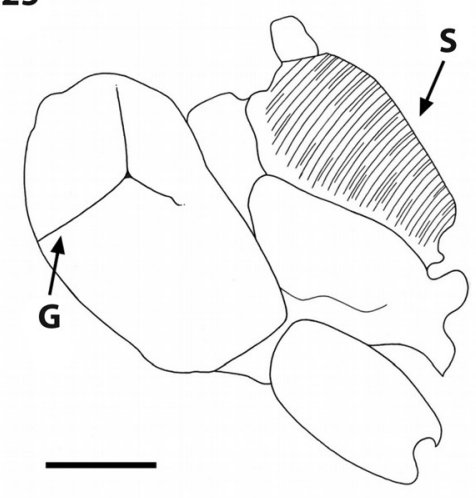

26

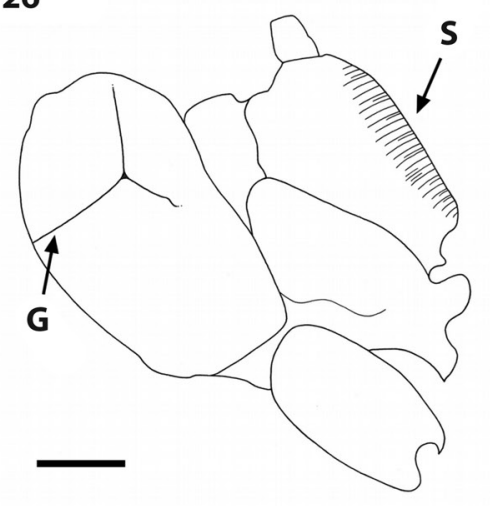

27

28

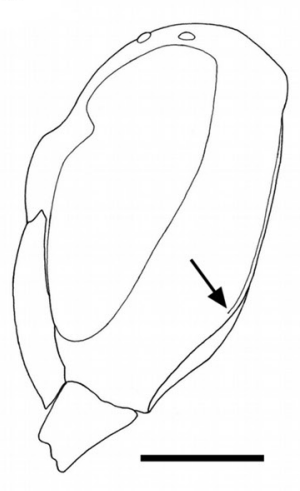

29

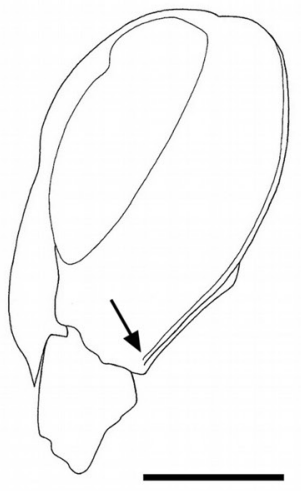

30

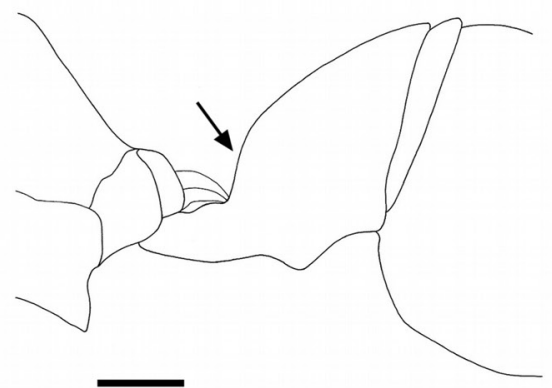

Figs. 24-30. Polistes species. 24. P. pacificus mesepisternum showing epicnemial groove (arrow), lateral view, pronotum above. 25-26. Mesosoma (excluding pronotum), lateral view, showing dorsal groove (G) on mesepisternum and striae (S) on propodeum, in $P$. canadensis (25) and $P$. goeldii (26). 27. P. occipitalis head, oblique lateral view, showing flange (arrow) formed by occipital carina. 28-29. Head, lateral view, showing relative extension of occipital carina (arrow indicates ventral limit) in P. pacificus (28) and P. bicolor (29). 30. P. bicolor first metasomal tergum, lateral view, showing upward slope of about $70^{\circ}$ (arrow) beyond reception of propodeal muscle. 
31

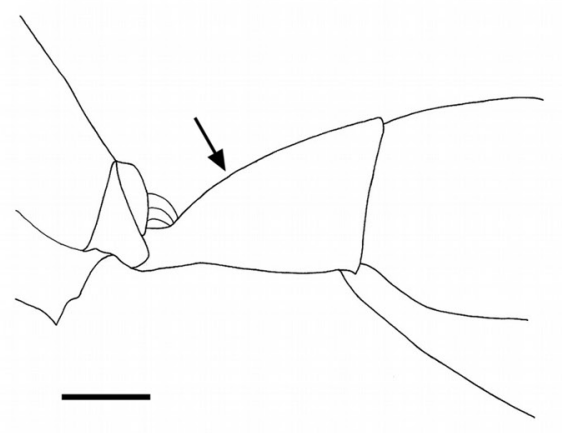

33

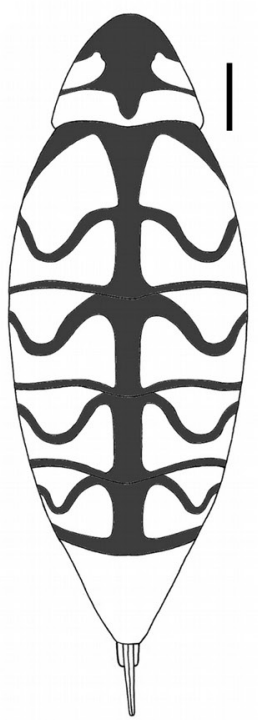

37

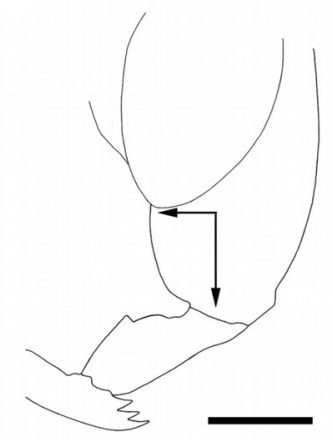

34
32
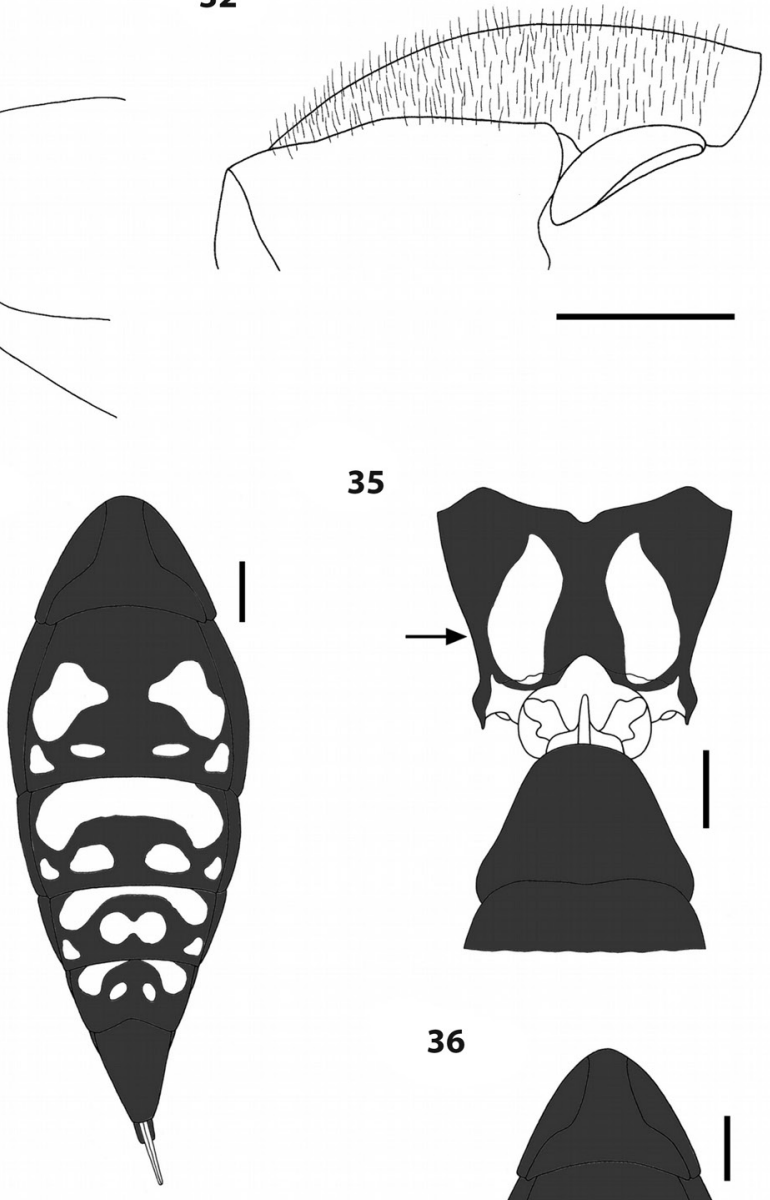

35

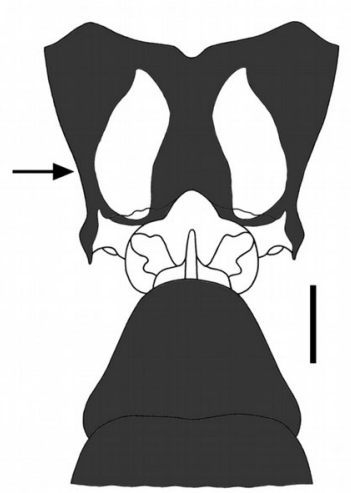

36

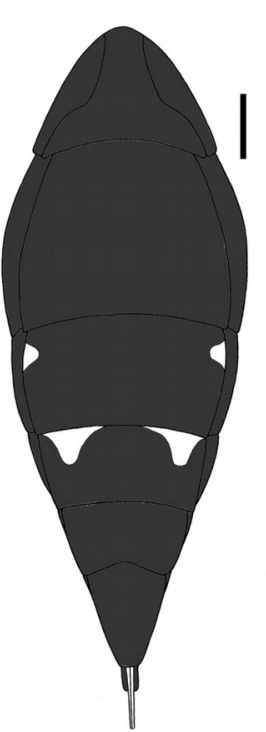

Figs. 31-38. Polistes species. 31. $P$. deceptor first metasomal tergum, lateral view, showing upward slope of about $45^{\circ}$ (arrow) beyond reception of propodeal muscle. 32. P. oculatus mesoscutum, lateral view, showing conspicuous hairs. 33-34. P. myersi metasomal color pattern in dorsal (33) and ventral (34) view. 35. P. myersi propodeal color pattern (arrow), posterodorsal view. 36. $P$. versicolor metasomal color pattern, ventral view. 37-38. Malar space, oblique anterior view, showing relative width (hoizontal arrow) and length (vertical arrow) in P. carnifex (37) and P. erythrocephalus (38). 
39

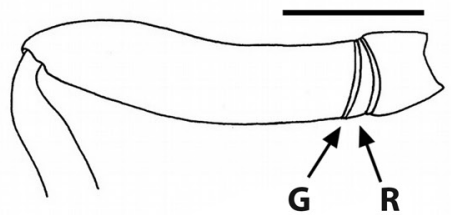

42

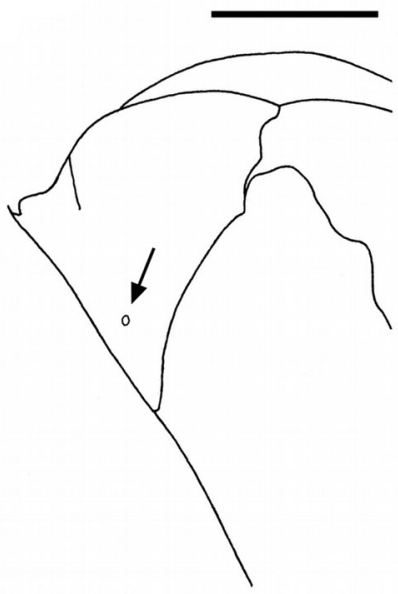

44

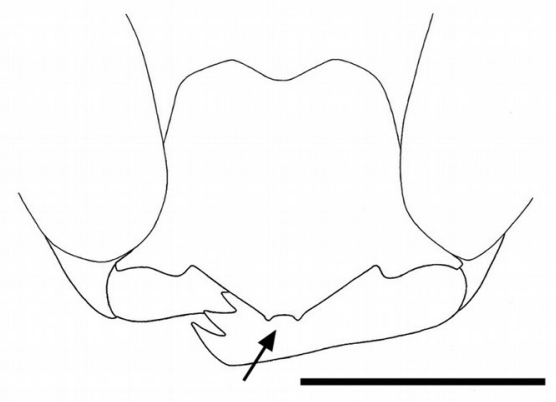

43
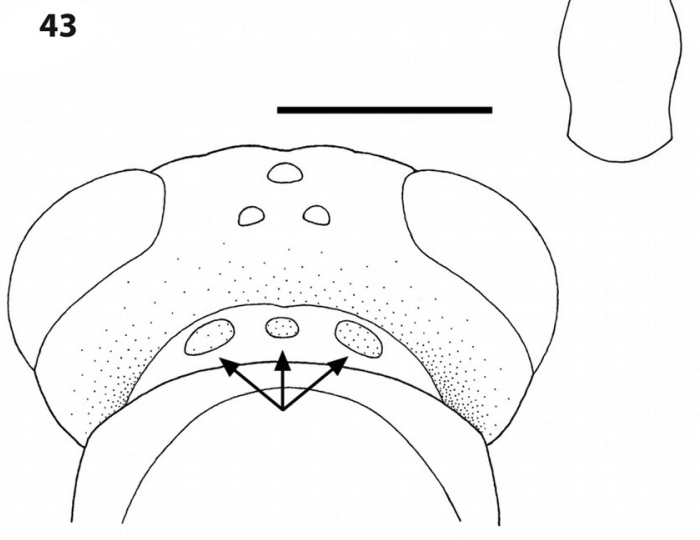

45

40
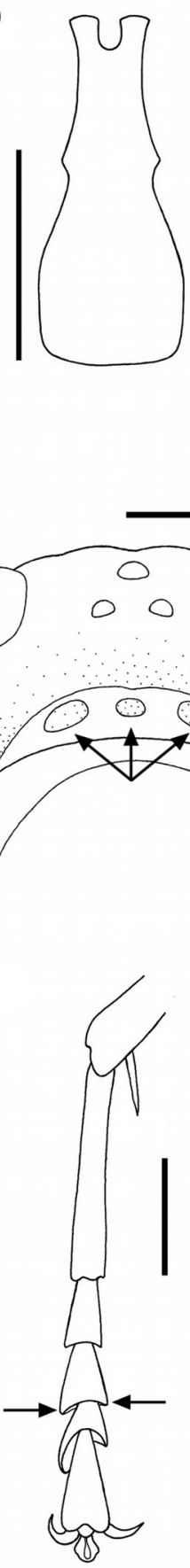

41

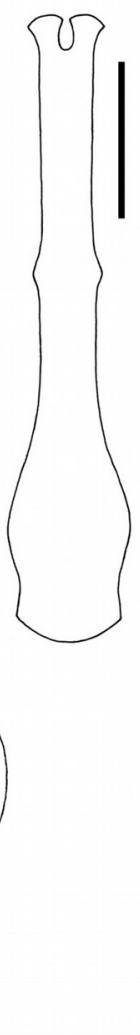

46

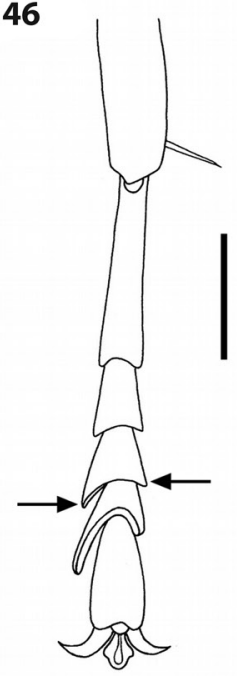

Figs. 39-46. Mischocyttarus species. 39. M. melanarius fore femur, lateral view, showing groove $(\mathrm{G})$ which delimits a ring (R) at base of femur (next to coxa). 40-41. First metasomal tergum, dorsal view, of M. carbonarius (40) and M. melanarius (41). 42. M. basimacula pronotum, lateral view, showing fovea (arrow). 43. M. collarellus head and pronotum, posterodorsal view, showing translucent "windows" (arrows) on raised anterior margin of pronotum. 44. M. nigroclavatus clypeus, anterior view, showing bidentate apex (arrow). 45-46. Middle tarsus, posterodorsal view, of M. mastigophorus (45) with third segment hardly asymmetrical (arrows) and M. basimacula (46) with third segment distinctly asymmetrical (arrow). 
47

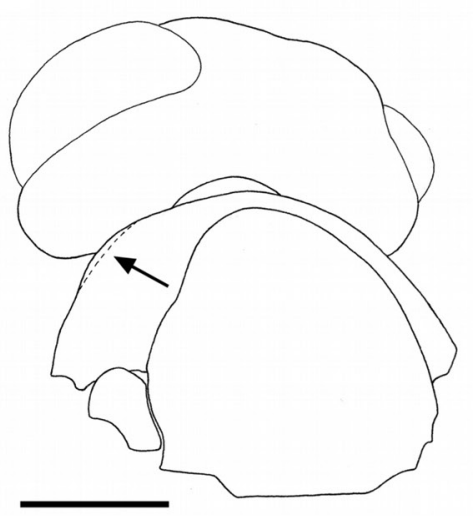

49

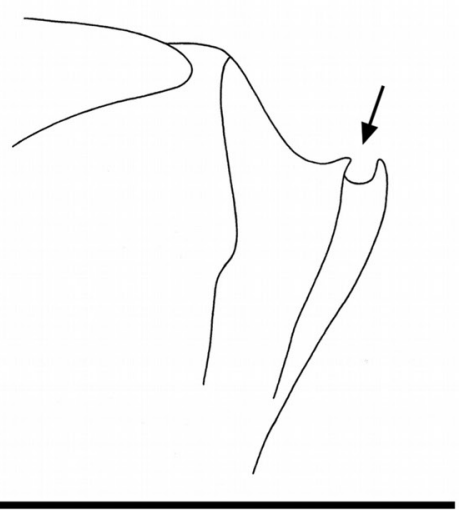

51

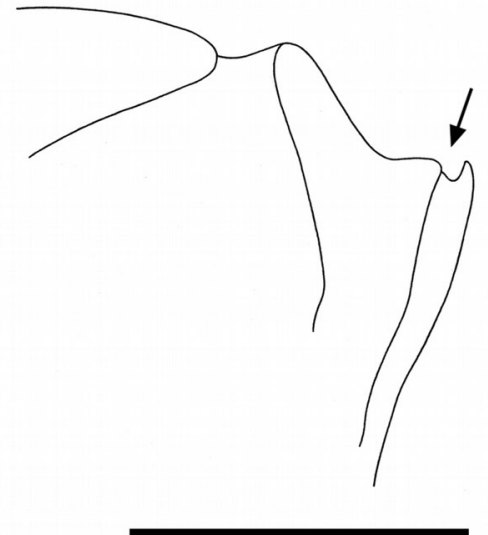

48

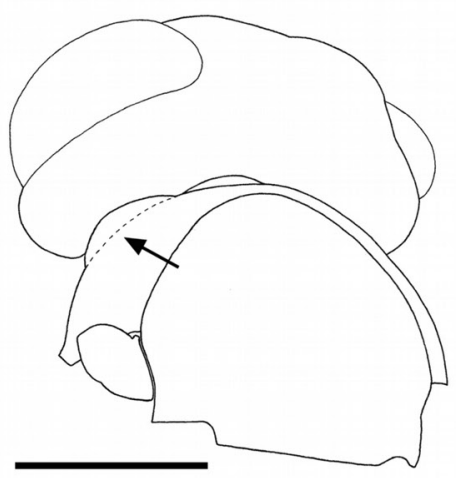

50

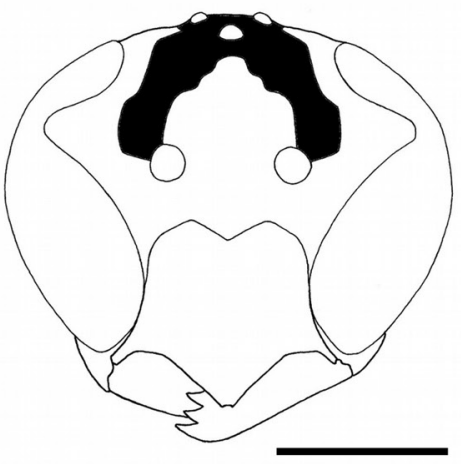

52

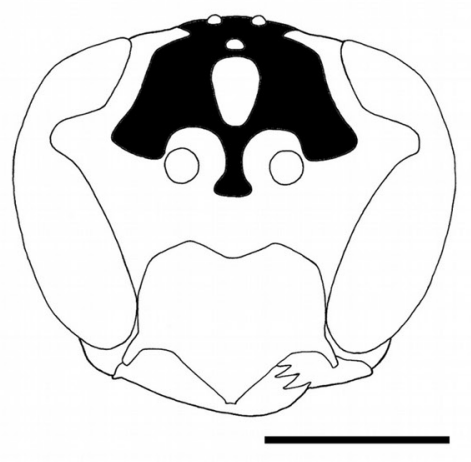

Figs. 47-52. Mischocyttarus species. 47-48. Head and anterior mesosoma, oblique posterodorsal view, of M. pallidipectus (47) with pronotal carina weak laterally (arrow) and M. costaricensis (48) with pronotal carina forming a raised shoulder (arrow). 49. M. basimacula pronotum, lateral view, showing deep furrow on anterior margin (arrow). 50. M. basimacula frons and vertex color pattern, anterior view. 51. $M$. costaricensis pronotum, lateral view, showing shallow furrow on anterior margin (arrow). 52. M. costaricensis frons and vertex color pattern, anterior view. 
53

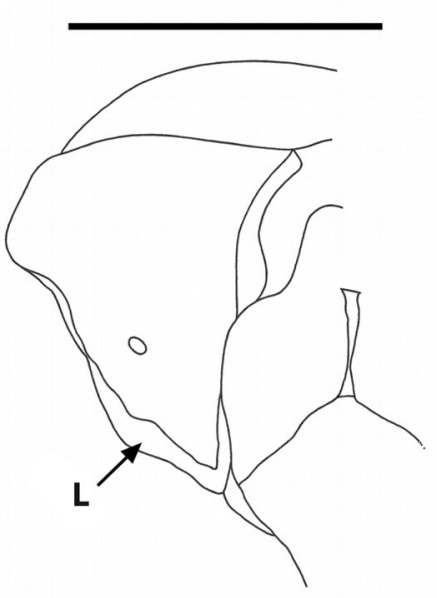

55

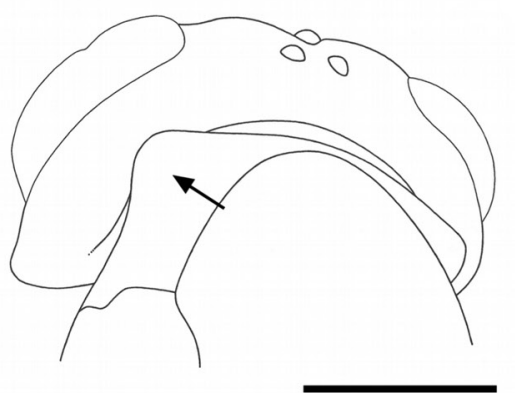

54

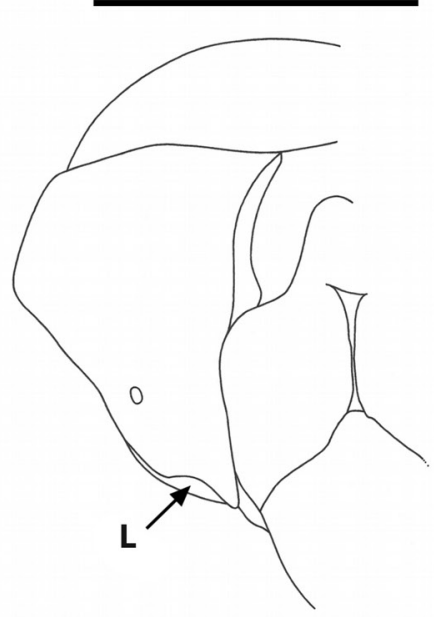

56

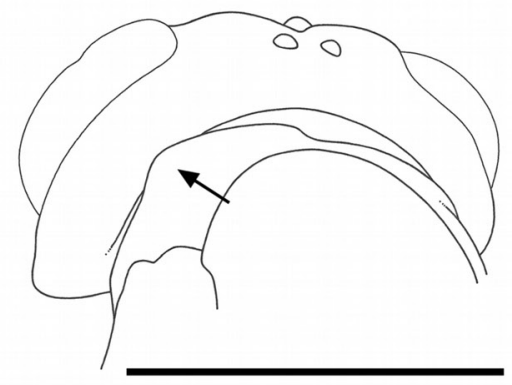

57

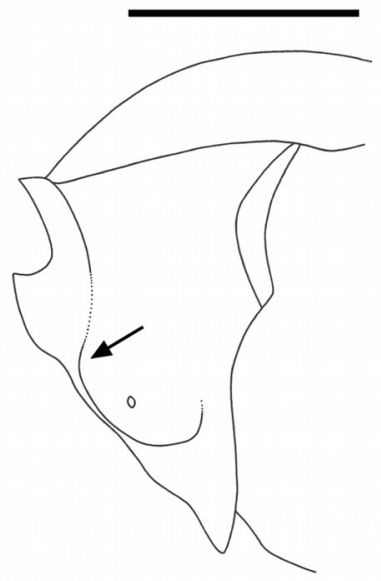

58

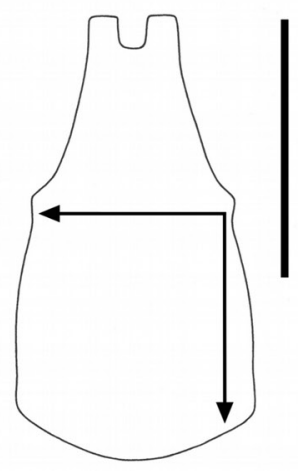

59

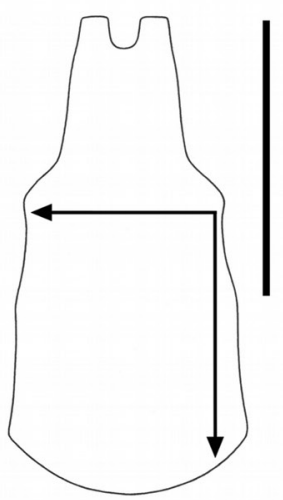

Figs. 53-59. Agelaia species. 53-54. Pronotum, lateral view, showing lamella (L) on anterior margin of $A$. pleuralis (53) and $A$. cajennensis (54). 55-56. Head and anterior mesosoma, oblique posterodorsal view, showing angular lateral margin (arrow) of pronotal carina in A. angulicollis (55) and more rounded lateral marigin (arrow) in A. areata (56). 57. A. xanthopus pronotum, lateral view, showing strongly raised pronotal carina (arrow). 58-59. First metasomal tergum, dorsal view, showing relative width (horizonal arrow) vs length (vertical arrow) of area behind spiracles in $A$. areata (58) and $A$. yеросара (59). 
60

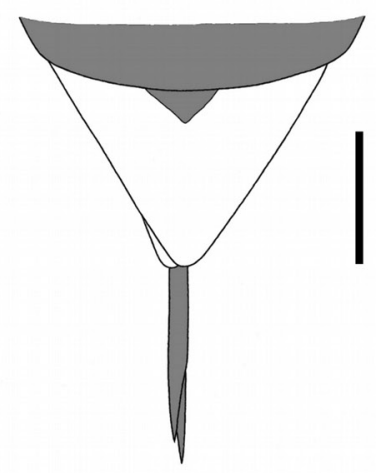

62

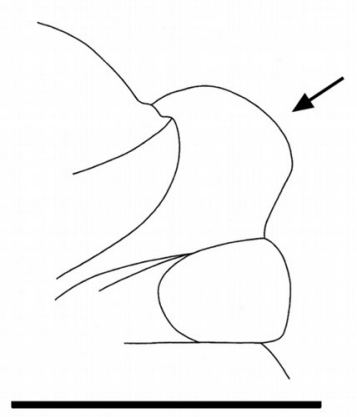

63

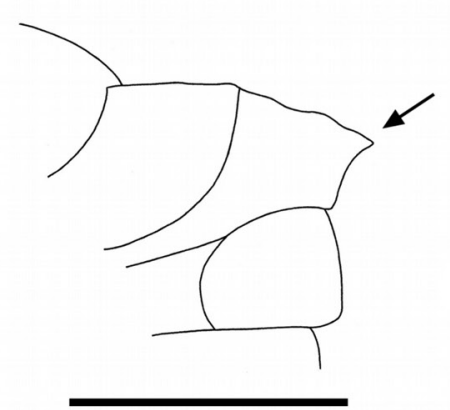

\section{1}

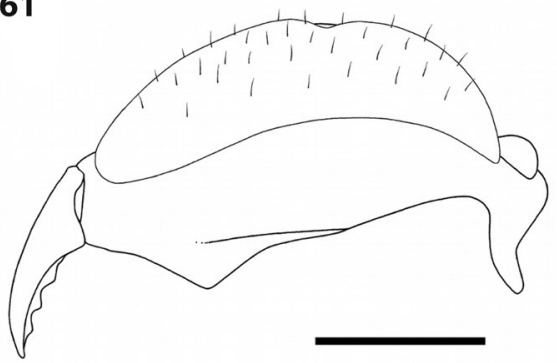

64
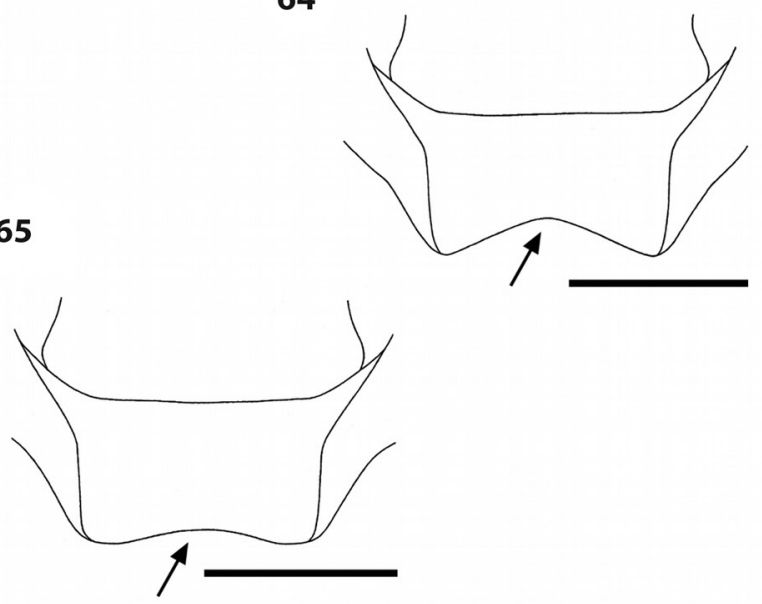

66
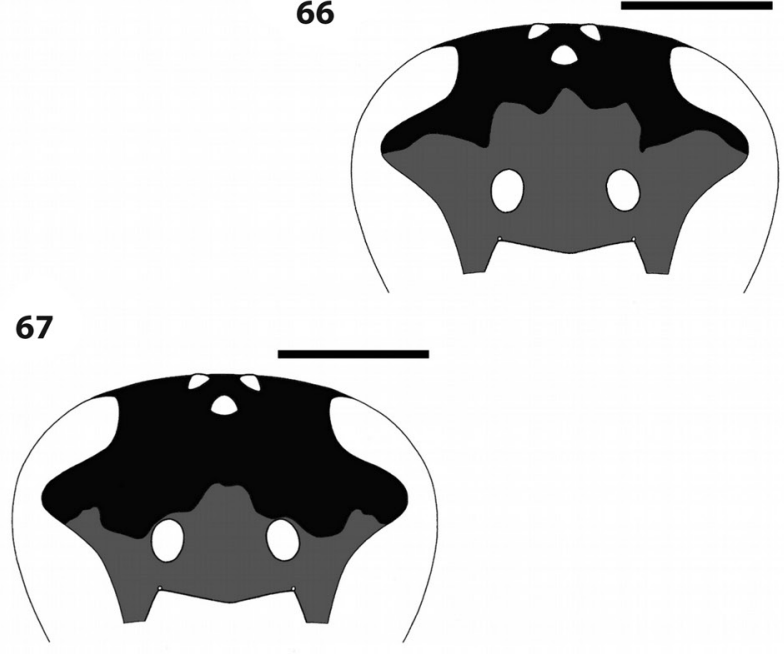

Figs. 60-67. Apoica, Brachygastra and Chartergellus species. 60. A. pallida sixth metasomal tergum color pattern, dorsal view. 61. A pallida left eye, posterolateral view, showing hairs. 62-63. Scutellum, lateral view, showing rounded margin (arrow) in B. scutellaris (62) and angular margin (arrow) in B. mellifica (63). 64-65. Scutellum, dorsal view, showing emarginate posterior edge (arrow) in B. lecheguana (64) and weakly emarginate posterior edge (arrow) in B. mellifica (65). 66-67. Frons color pattern, anterior view, in C. golfitensis (66) and C. atectus (67). 
68

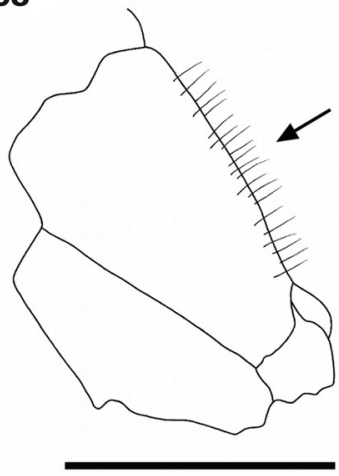

69

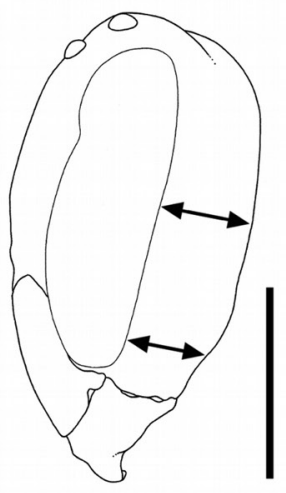

70

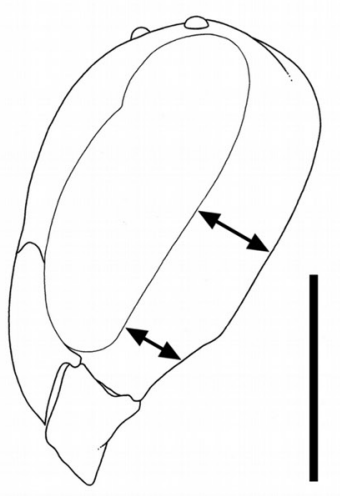

71

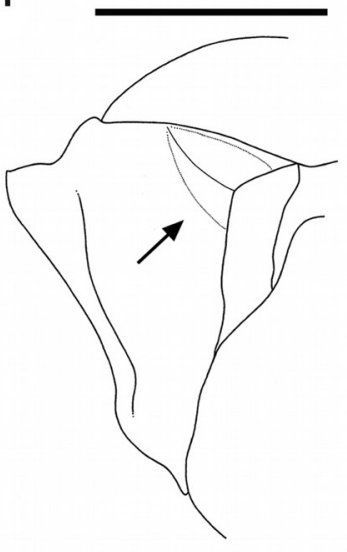

72

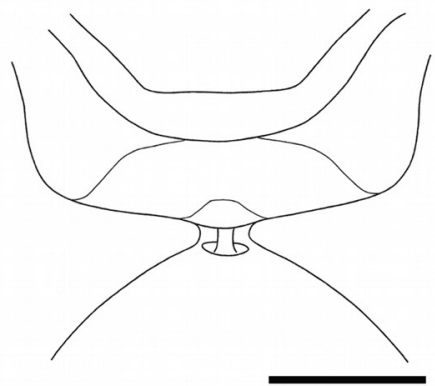

75
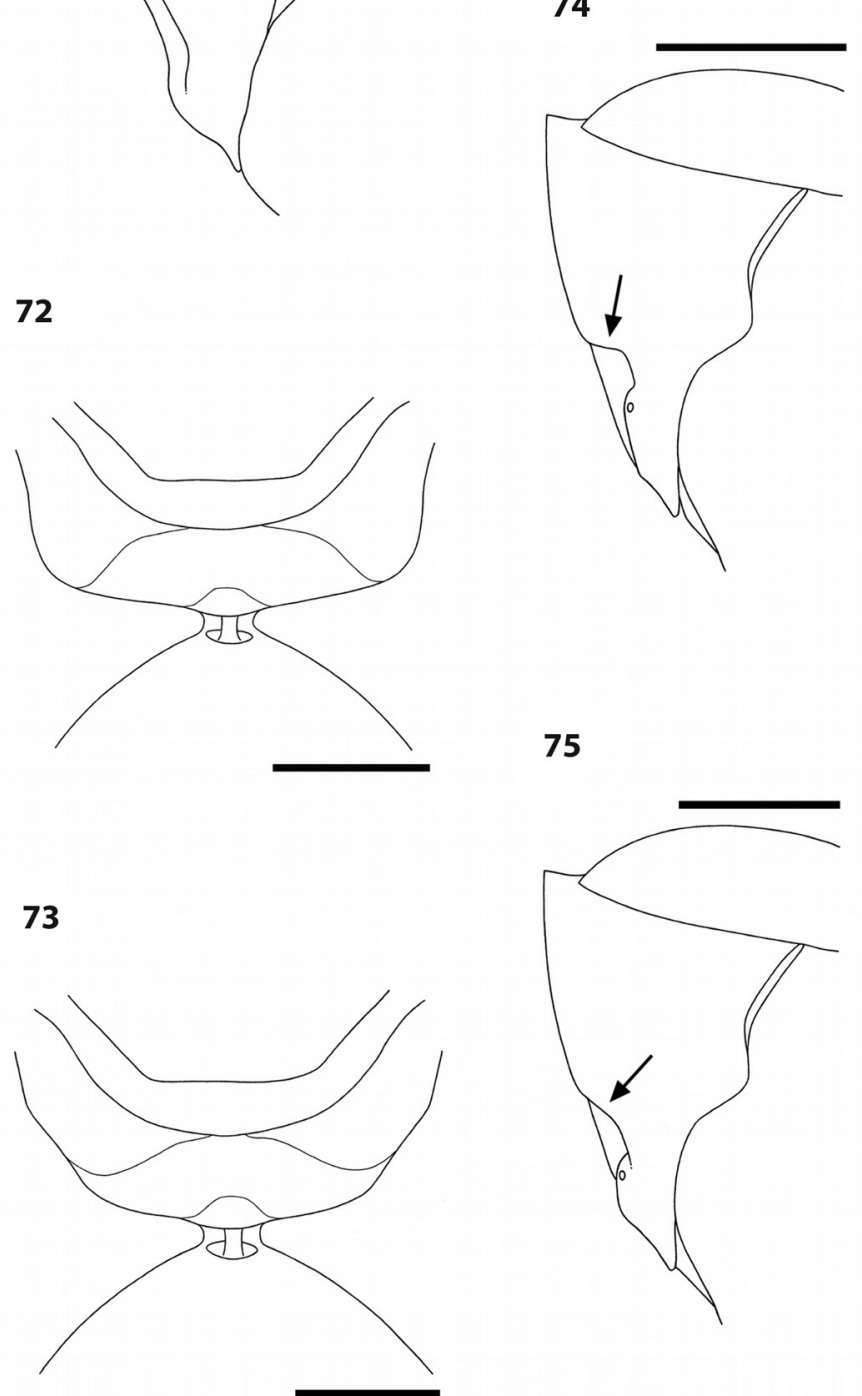

Figs. 68-75. 68. Metapolybia and Parachartergus species. 68. M. mesoamerica propodeum, lateral view, showing erect hairs (arrow). 69-70. Head, lateral view, showing dorsal and ventral width (arrows) of gena in M. mesoamerica (69) and M. aztecoides (70). 71. M. aztecoides, pronotum lateral view, showing protruding humerus (arrow). 72-73. Propodeum, posterodorsal view, showing quadrate posterolateral margins in P. fraternus (72) and rounded margins in P. apicalis (73). 74-75. Pronotum, lateral view, showing strongly curved carina (arrow) in P. apicalis (74) and weakly curved carina (arrow) in P. aztecus (75). 
76

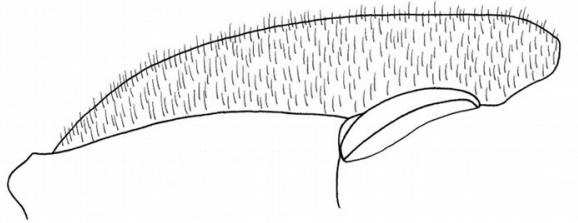

78

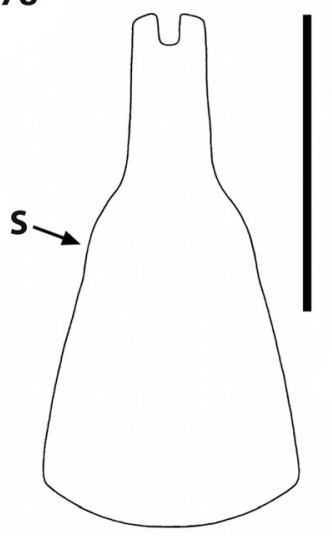

79

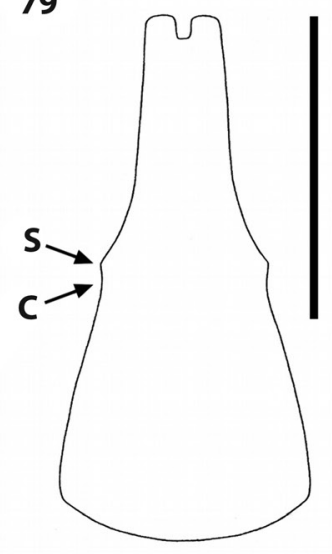

80

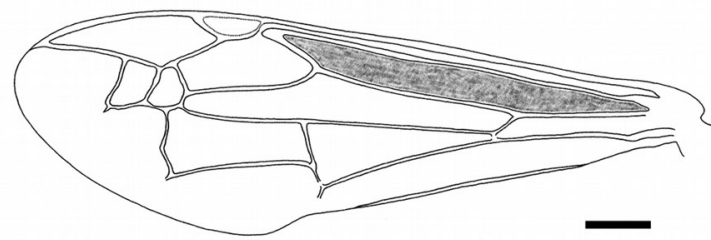

81

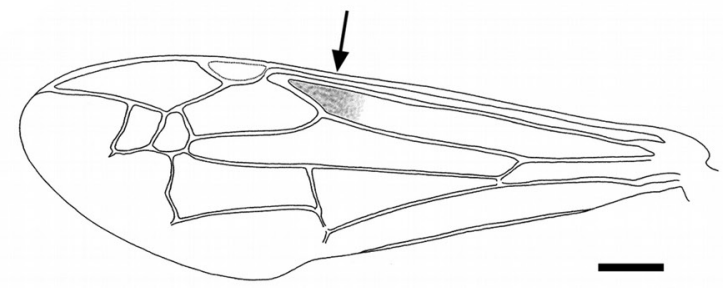

77

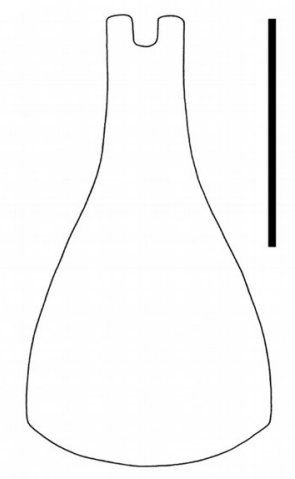

82

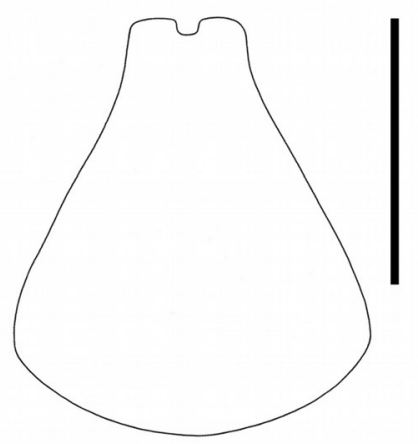

83

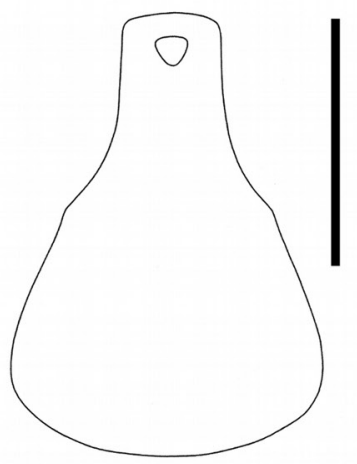

Figs. 76-83. Polybia species. 76. . emaciata mesoscutum, lateral view, showing short erect hairs. 77-79. First metasomal tergum, dorsal view, of $P$. nidulatrix (77), P. bistriata (78) and P. selvana (79) showing spiracular area (S) and concavity (C). 80-81. Fore wing basal cell color pattern in P. raui (80) and P. ignobilis (81). 82-83. First metasomal tergum, dorsal view, of P. bifasciata (82) and P. barbouri (83). 
84

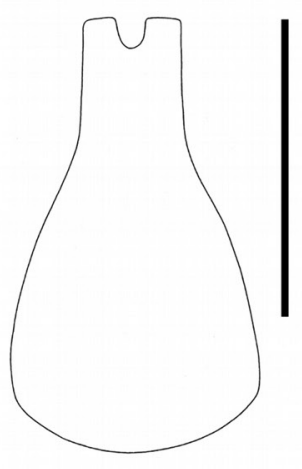

85

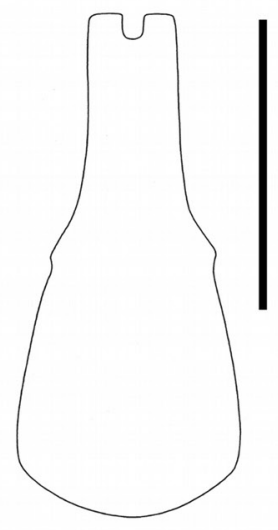

86

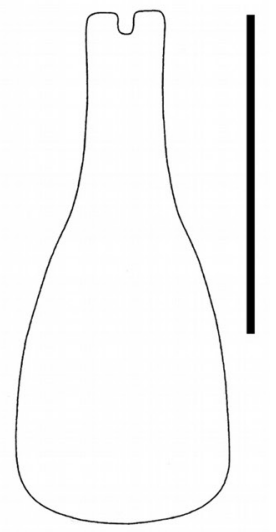

87

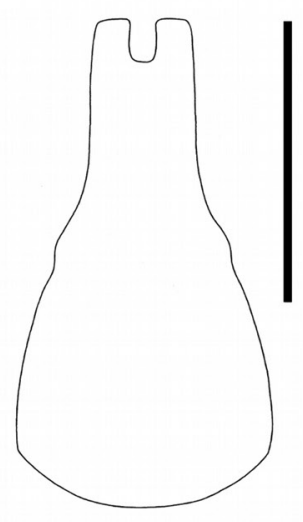

89

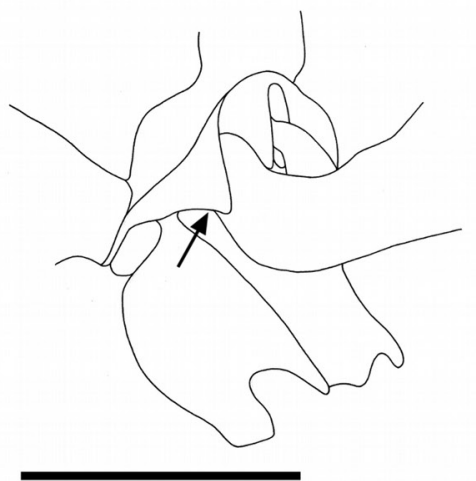

88

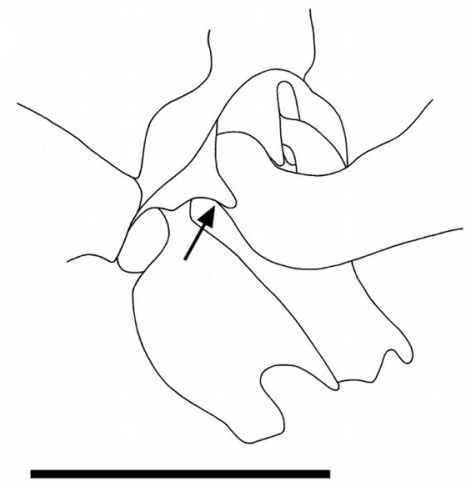

90

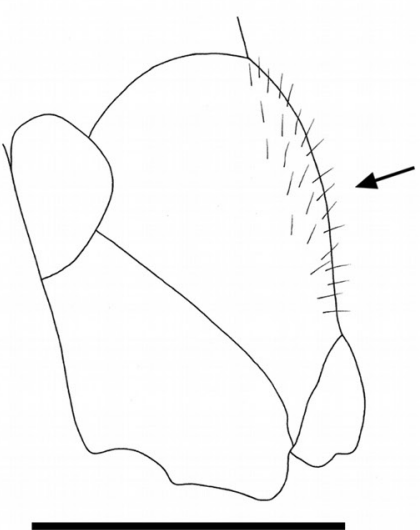

Figs. 84-90. Polybia species. 84-87. First metasomal tergum, dorsal view. of P. scrobalis (84), P. plebeja (85), P. belemensis (86), and $P$. occidentalis (87). 88-89. Shape of the propodeal valvula (arrow), oblique posterior view, of $P$. bifasciata (88) and $P$. barbouri (89). 90. $P$. occidentalis propodeum, lateral view, showing conspicuous hairs. 
91

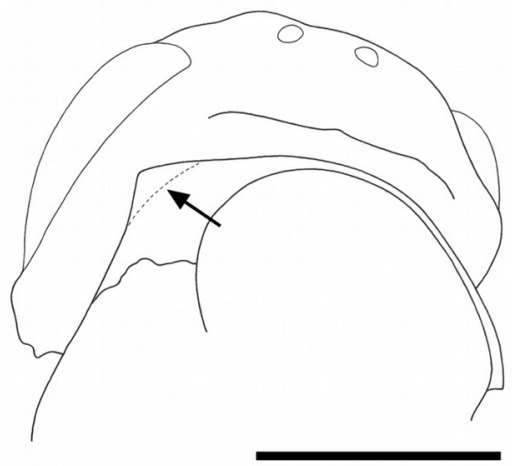

93

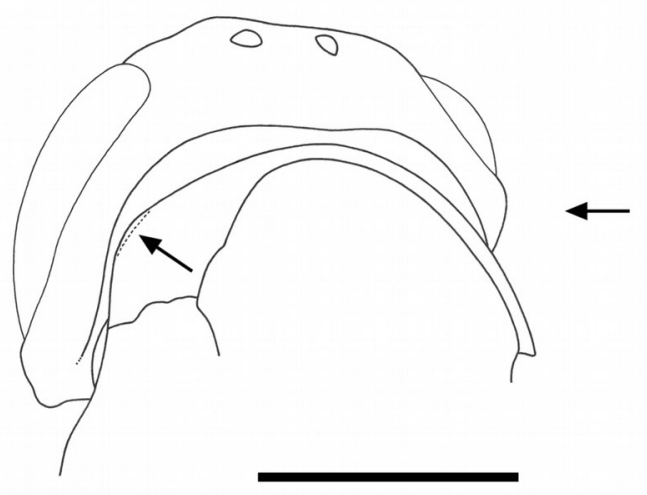

95

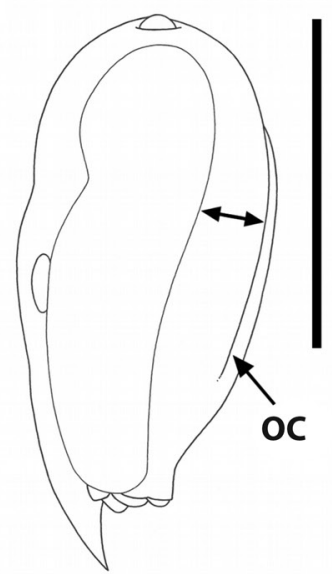

92

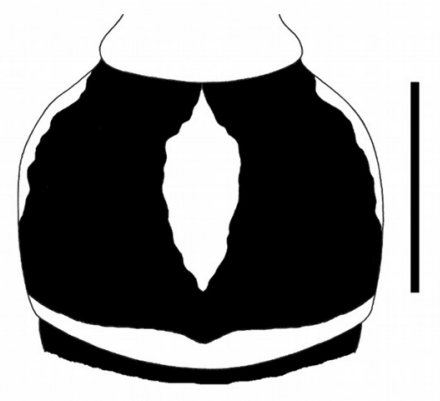

94

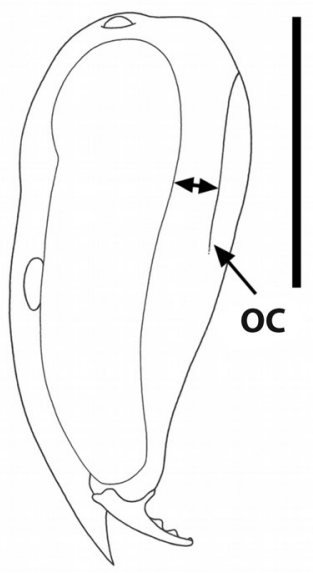

96

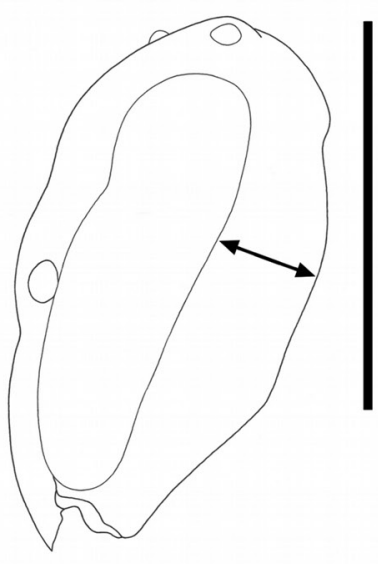

Figs. 91-96. Protopolybia species. 91. $P$. wheeleri, head and anterior mesosoma, oblique posterodorsal view, showing pointed anterior lateral margin of pronotum (arrow). 92. $P$. wheeleri second metasomal tergum color pattern, dorsal view. 93. $P$. picteti, head and anterior mesosoma, oblique posterodorsal view, showing rounded anterior lateral margin of pronotum (arrow). 94-96. Head, lateral view, showing width of gena (arrow) and occipital carina (OC) in P. fuscatus (94), P. panamensis (95) and $P$. acutiscutis (96). 
97

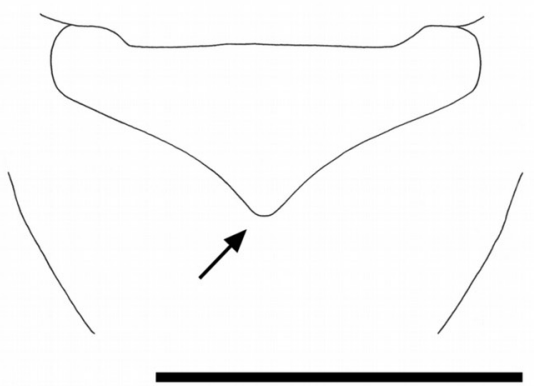

99

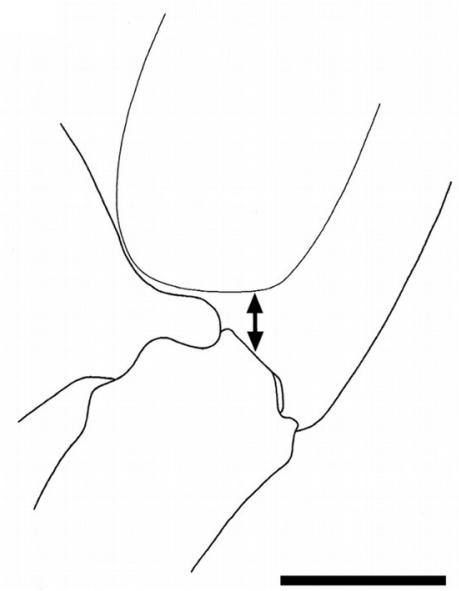

98

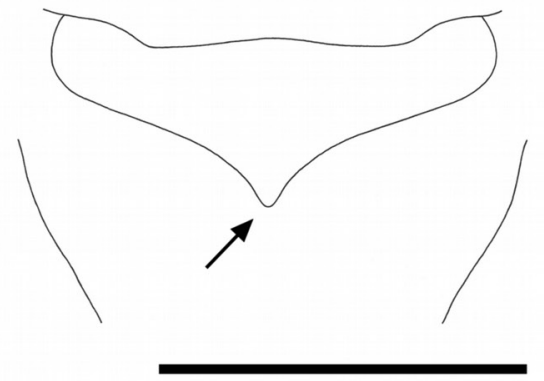

100

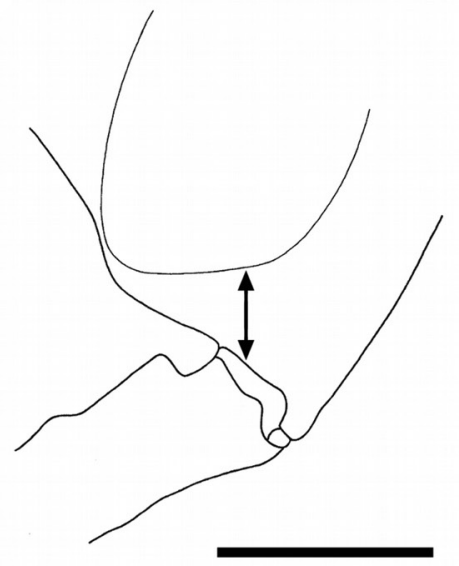

Figs. 97-100. Protopolybia and Synoeca species. 97-98. Metanotal process, posterodorsal view, in P. chartergoides (97) and P. panamensis (98). 99-100. Malar space (arrow), oblique anterior view, in S. chalibea (99) and S. septentrionalis (100). 